\title{
PENGARUH VARIABEL MUTU PELAYANAN TERHADAP KEPUASAN PASIEN DAN WORD OF MOUTH (MOM) DI PUSKESMAS KELUA KABUPATEN TABALONG
}

\author{
Rusmilawaty \\ Sekolah Tinggi Ilmu Ekonomi Pancasetia \\ Jl. Ahmad Yani Km. 5.5 Banjarmasin \\ milamarsha@gmail.com
}

\begin{abstract}
Abstrak : Penelitian ini merupakan penelitian penjelasan atau explanatory research. Analisis yang digunakan adalah analisis jalur (path analysis) yang merupakan suatu bentuk terapan dari analisis regresi berganda (multiple regression analisysis). Variabel dalam penelitian ini meliputi rasio Pengaruh Bersama Pengaruh Bukti Fisik (X1),Kehandalan(X2), Daya Tanggap(X3), Jaminan(X4), Kehandalan(X5), dan Kepuasan Pasien (Y1) Mempengaruhi secara Signifikant terhadap Word of Mouth (WOM) (Y2) sebagai variabel terikat. Populasi pada penelitian ini adalah Pasien Puskesmas Kelua Kabupaten Tabalong sebanyak 300 (Tiga Ratus) orang dan semuanya dijadikan sampel dalam penelitian ini. Dari hasil analisis data dapat diketahui pada sub struktur 1 terdapat pengaruh langsung dan tidak langsung yang signifikan antara Bukti Fisik (X1),Kehandalan(X2), Daya Tanggap(X3), Jaminan(X4), Kehandalan(X5), Terhadap Kepuasan Pasien (Y1) dan pada sub struktur 1 terdapat juga terdapat pengaruh langsung dan tidak langsung Bukti Fisik (X1),Kehandalan(X2), Daya Tanggap(X3), Jaminan(X4), Kehandalan(X5), dan Kepuasan Pasien (Y1) Mempengaruhi secara Signifikant terhadap Word of Mouth (WOM) (Y2)
\end{abstract}

Kata kunci: Bukti Fisik, Kehandalan, Daya Tanggap, Jaminan, Kehandalan, Kepuasan Pasien, dan Word of Mouth (WOM)

\section{Latar Belakang}

Untuk mencapai tujuan pembangunan kesehatan nasional diselenggarakan berbagai upaya kesehatan secara menyeluruh, berjenjang dan terpadu. Puskesmas adalah fasilitas pelayanan kesehatan yang menyelenggarakan upaya kesehatan masyarakat dan upaya kesehatan perseorangan tingkat pertama, dengan lebih mengutamakan upaya promotif dan preventif untuk mencapai derajat kesehatan masyarakat yang setinggitingginya di wilayah kerjanya (Permenkes, 2015).Puskesmas adalah suatu kesatuan organisasi kesehatan fungsional yang merupakan pusat pembangunan kesehatan masyarakat yang juga membina peran serta masyarakat di samping memberikan pelayanan secara menyeluruh dan terpadu kepada masyarakat di wilayah kerjanya dalam bentuk kegiatan pokok (Herlambang, 2016).

Puskesmas merupakan unit pelayanan terdepan dan langsung dapat menjangkau masyarakat, melaksanakan pelayanan kesehatan melalui upaya pokok kegiatan Puskesmas yang salah satunya pelayanan kesehatan dengan memberi pengobatan, Pelayanan kesehatan yang diberikan Puskesmas meliputi pengobatan rawat jalan dan rawat inap termasuk di dalamnya upaya peningkatan kesehatan, pencegahan penyakit, penyembuhan dan pemulihan kesehatan. Puskesmas sebagai fasiltas kesehatan tingkat pertama wajib menyediakan pelayanan kesehatan sesuai dengan peraturan perundangan yang berlaku dan pedoman dari Kementerian Kesehatan dengan memperhatikan kebutuhan dan harapan masyarakat. Jenisjenis pelayanan yang disediakan perlu diketahui dan dimanfaatkan secara optimal oleh masyarakat, sebagai wujud pemenuhan akses masyarakat terhadap pelayanan yang dibutuhkan (Permenkes No. 46 Tahun 2015).

Mutu dan kinerja pelayanan perlu diupayakan untuk ditingkatkan secara berkesinambungan, oleh karena itu umpan balik dari masyarakat dan pengguna 
pelayanan Puskesmas secara aktif diidentifikasi sebagai bahan untuk penyempurnaan pelayanan Puskesmas. Untuk menjamin bahwa perbaikan mutu, peningkatan kinerja dilaksanakan secara berkesinambungan, maka perlu dilakukan penilaian oleh pihak eksternal dengan menggunakan standar yang ditetapkan yaitu melalui mekanisme akreditasi (Permenkes, 2015).

Layanan kesehatan yang bermutu adalah layanan kesehatan yang selalu berupaya memenuhi harapan pasien sehingga pasien akan selalu merasa berhutang budi serta sangat berterima kasih. Akibatnya, pasien akan bercerita kemanamana dan kepada setiap orang untuk menyebarluaskan segala hal yang baik tersebut sehingga pasien atau masyarakat akan berperan menjadi petugas hubungan masyarakat dari setiap organisasi layanan kesehatan yang baik mutunya (Pohan, 2007).

Pelayanan yang bermutu merupakan salah satu komponen penentu kepuasan pasien dirumah sakit. Perawat dituntut untuk memberikan pelayanan keperawatan yang bermutu agar dapat meningkatkan kepuasan pasien. Pelayanan keperawatan adalah pelayanan professional yang diberikan oleh perawat sesuai dengan standar pelayanan yang mana pelayanan yang diterima melebihi harapan pasien (Nursalam, 2011). Dengan demikian perawat harus dapat memberikan pelayanan keperawatan yang terbaik kepada pasien.

Kepuasan adalah merupakan respon pelanggan sebagai hasil dan evaluasi ketidaksesuaian kinerja atau tindakan yang di rasakan sebagai akibat dari tidak terpenuhinya harapan (Tjiptono, 2006). Tingkat kepuasan merupakan fungsi dari perberdaan antara kinerja yang di rasakan dan harapan. Apabila kinerja di bawah harapan, maka pelanggan akan kecewa dan tidak puas. Bila kinerja sesuai dengan harapan, pelanggan akan puas. Sedangkan kinerja yang melebihi harapan, pelanggan akan merasa sangat puas. Harapan pelanggan dapat di bentuk oleh penglaman masa lampau, kometar dari kerabatnya (Supranto, 2006)
Kepuasan pasien merupakan salah satu indikator penting yang harus diperhatikan dalam pelayanan kesehatan. Kepuasan pasien adalah hasil penilaian dari pasien terhadap pelayanan kesehatan dengan membandingkan apa yang diharapkan sesuai dengan kenyataan pelayanan kesehatan yang diterima disuatu tatanan kesehatan rumah sakit (Kotler, 2007 ; Pohan, 2007). Dengan demikian kepuasan pasien dirumah sakit tergantung bagaimana pelayanan yang diberikan oleh pihak rumah sakit tersebut. Namun pelayanan yang diberikan masih ada yang belum sesuai dengan apa yang diinginkan oleh pasien dan kepuasan pasien masih belum sesuai dengan standar.

Standar kepuasan pasien di pelayanan kesehatan ditetapkan secara nasional oleh Departemen Kesehatan. Menurut Peraturan Kementrian Kesehatan Republik Indonesia Tahun 2016 tentang Standar Pelayanan Minimal untuk kepuasan pasien yaitu diatas 95\% (Kemenkes, 2016). Bila ditemukan pelayanan kesehatan dengan tingkat kepuasaan pasien berada dibawah 95\%, maka dianggap pelayanan kesehatan yang diberikan tidak memenuhi standar minimal atau tidak berkualitas. Beberapa hasil penelitian menunjukan data tentang tingkat kepuasan pasien di berbagai Negara. Tingkat kepuasan pasien menurut Ndambuki tahun 2013 di Kenya menyatakan 40,4\%, kepuasan pasien di Bakhtapur India menurut Twayana 34,4\%., sedangkan di Indonesia menunjukkan angka kepuasaan pasien $42,8 \%$ di Maluku Tengah dan $44,4 \%$ di Sumatra Barat (Latupono, 2014 ; Sari, 2014). Berdasarkan data tersebut dapat disimpulkan bahwa angka kepuasaan pasien masih tergolong rendah, sehingga kepuasaan pasien menjadi permasalahan rumah sakit baik di Indonesia maupun di luar negeri.

pasien akan berdampak terhadap perkembangan rumah sakit. Pada pasien yang merasa tidak puas terhadap layanan kesehatan yang diterima, maka pasien memutuskan akan pindah ke rumah sakit lain yang dapat memberikan pelayanan 
yang lebih baik (Kotler, 2007). Penelitian oleh Irmawati dan Kurniawati tahun 2014 menunjukkan bahwa keputusan pasien untuk menggunakan layanan kesehatan dipengaruhi oleh kualitas layanan rumah sakit. Dengan demikian kurangnya kepuasan pasien dapat menimbulkan hilangnya kepercayaan pasien terhadap rumah sakit tersebut.

Perawat merupakan salah satu tenaga kesehatan yang memegang peranan penting dalam pelayanan kesehatan dirumah sakit. Perawat memiliki peran memberikan asuhan keperawatan yang berkualitas karena perawat berinteraksi langsung selama 24 jam dengan pasien, dan jumlah perawat yang mendominasi sehingga perawat harus mampu memberikan pelayanan keperawatan yang bermutu (Nursalam, 2011). Oleh karena itu pelayanan keperawatan memiliki kontribusi yang besar dalam meningkatkan mutu pelayanan rumah sakit.

Word of Mouth adalah salah satu strategi pemasaran yang penting yang dapat dipengaruhi oleh kepuasan pelanggan yang didapat berdasarkan nilai yang dirasa dan citra merek suatu perusahaan. Word of Mouth juga diperlukan dalam dunia kesehatan untuk dapat memperoleh banyak pasien dan meningkatkan kepuasan pasien. Begitu juga dengan Puskesmas yang membutuhkan Word of Mouth untuk dapat terus meningkatkan kepuasan pasien dengan memberikan nilai/manfaat yang maksimal bagi pasiennya Word of Mouth adalah usaha pemasaran yang memicu pasien untuk senantiasa membicarakan, mempromosikan, merekomendasikan, dan menjual produk dan jasa atau merek kepada konsumen lainnya (Kotler dan Keller, 2007:204).

Sebuah survey yang dilakukan oleh Nielsen menyebutkan bahwa $77 \%$ konsumen cenderung akan membeli sebuah produk dan jasa setelah mereka mempelajarinya dari teman atau keluarga. Sementara $92 \%$ orang percaya terhadap rujukan terhadap suatu produk dan jasa dari orang yang mereka kenal. Sementara itu, dari sisi pelaku bisnis, cara terbaik untuk menjalankan strategi ini adalah dengan memberikan kualitas produk dan jasa yang terbaik. Konsumen akan dengan sukarela membagikan informasi kepada rekanrekannya bila ia puas atau mungkin kecewa terhadap produk dan jasa.

Berbeda dengan strategi pemasaran lain yang membutuhkan biaya, strategi pemasaran yang satu ini tidak membutuhkan biaya sama sekali. Kuncinya, kualitas produk dan jasa dan pelayanan yang baik. Itu adalah harga mati agar informasi positif mengenai produk dan jasa Anda, dapat tersebar ke berbagai orang melaui mulut ke mulut. Dikutip dari entrepreneur.com sebuah bisnis harus fokus menciptakan layanan yang dapat mengubah pelanggan menjadi penggemar yang tidak berhenti membicarakan produk dan jasa Anda. Bila sudah sampai pada tahap tersebut, itu sudah mengindikasikan bahwa prduk Anda sudah melampaui ekspektasi pelanggan dengan kualitas produk dan jasa maupun layanan yang Anda berikan.

Untuk bisa sampai tahap ini, tentu tidak cukup dengan hanya membuat produk dan jasa yang berkualitas. Tetapi mempetimbangkan juga faktor-faktor lain yang memuaskan pelanggan. Pelanggan harus mampu merasa bahwa ia tidak sekadar membeli sebuah produk dan jasa, tetapi terbantu atau merasa lebih baik ketika membeli produk dan jasa tersebut.

Word of mouth dapat terbentuk dikarenakan beberapa faktor yang mempengaruhinya, yang salah satunya adalah kepuasan pasien. Kepuasan pasien merupakan tujuan dari Puskesmas di Kabupaten Tabalong agar semua masyarakat atau pasien yang menerima jasa pelayanan kesehatan di Puskesmas di Kabupaten Tabalong puas, sehingga bisa merekomendasikannya dengan pasien lainnya dengan berobat di Puskesmas dengan biaya terjangkau dan pelayanan yang baik.

Strategi pemasaran dari mulut ke mulut atau yang disebut juga sebagai word of mouth merupakan strategi pemasaran tradisional yang sudah lama dikenal. Meskipun disebut sebagai strategi pemasaran tradisional, namun strategi ini 
masih dianggap sebagai salah satu strategi yang paling efektif. Pemasaran dari mulut ke mulut terbilang efektif karena orang memiliki kecenderungan untuk mempercayai informasi orang yang dikenalnya. Dengan kata lain, informasi yang diberikan seseorang tentang suatu produk dan jasa kepada orang lain sama atau lebih besar efektifnya dengan iklan.

Dari hasil data tersebut, peneliti tertarik untuk meneliti tentang "Pengaruh Variabel Mutu Pelayanan Terhadap Kepuasan Pasien dan Word Of Mouth (MOM) di Puskesmas Kelua Kabupaten Tabalong.

\section{Studi Literatur}

\section{Pengertian Mutu Pelayanan Kesehatan}

Menurut Pohan (2006) Pelayanan kesehatan yang bermutu adalah suatu pelayanan kesehatan yang dibutuhkan, dalam hal ini akan ditentukan oleh profesi layanan kesehatan dan sekaligus diinginkan baik oleh pasien ataupun masyarakat serta terjangkau oleh daya beli masyarakat, sedangkan jaminan mutu pelayanan kesehatan adalah upaya yang sistematis dan berkesinambungan dalam memantau dan mengukur mutu serta melakukan peningkatan mutu yang di perlukan agar mutu pelayanan kesehatan senantisa sesuai dengan standart layanan kesehatan yang di sepakati.

\section{Dimensi Mutu Pelayanan Kesehatan}

Pelayanan kesehatan yang bermutu adalah suatu layanan kesehatan yang di butuhkan. Dalam hal ini akan di tentukan oleh profesi layanan kesehatan dan sekaligus di inginkan baik oleh pasien atupun masyarakatnya. Pelayanan kesehatan di tentukan oleh beberapa dimensi pokok. Menurut Parasuraman, et al (2006) dimensi dari mutu pelayanan kesehatan untuk mengukur mutu pelayanan kesehatan yang dikenal model SERVQUAL (service quality), teori ini digunakan sebagai landasan konsep penelitian ini. Lima dimensi mutu pelayanan adalah:

1. Bukti Langsung (Tangibels) Wujud kenyataan secara fisik yang meliputi penampilan dan kelengkapan fasilitas fisik seperti ruang perawatan, gedung, tersedianya tempat parkir kebersihan, kerapian, dan kenyamanan ruangan tunggu dan ruang pemeriksaan, kelengkapan peralatan komunikasi dan penampilan.

2. Kehandalan (Reliability) Dimensi ini menunjukkan kemampuan untuk memberikan pelayanan dengan sesuai janji yang ditawarkan. Penilaian ini berkaitan dengan ketepatan waktu pelayanan waktu mengurus pendaftaran, waktu pengobatan/pemeriksaan, kesesuaian antara harapan dan realisasi waktu bagi pasien.

3. Daya tanggap (Responsiveness) Respon atau kesigapan serta kemampuan untuk membantu pelanggan dan meningkatkan kecepatan pelayanannya. Dimensi ini juga dapat menunjukkan kesiapan pekerja untuk melayani pelanggan.

4. Jaminan (Assurance) Kemampuan karyawan atas pengetahuan terhadap produk secara tepat, jaminan keselamatan, keterampilan dalam memberikan keamanan, dalam memanfaatkan jasa yang ditawarkan dan kemampuan dalam menanamkan kepercayaan pelanggan terhadap perusahaan.

5. Kepedulian (Empathy) Memberikan perhatian secara individual penuh kepada pasien dan keluarganya, seperti kemudahan untuk menghubungi, kemampuan untuk berkomunikasi, perhatian yang tinggi kepada pasien.

\section{Manfaat Mutu Pelayanan Kesehatan}

Menurut Azwar (1996) program menjaga mutu adalah suatu upaya yang dilakukan secara berkesinambungan, sistematis, objektif, dan terpadu dalam menetapkan masalah dan penyebab masalah mutu pelayanan kesehatan berdasarkan standar yang telah ditetapkan, menetapkan dan melaksanakan cara penyelesaikan masalah sesuai dengan kemampuan yang tersedia, serta menilai hasil yang dicapai dan menyusun saran- 
saran tindak lanjut untuk lebih meningkatkan mutu pelayanan. Adapun manfaat dari program jaminan mutu, adalah

1). Dapat meningkatkan efektifitas pelayanan kesehatan. Peningkatan efektifitas pelayanan kesehatan ini erat hubungannya dengan dapat diatasinya masalah kesehatan yang tepat, karena pelayanan kesehatan yang diselenggarakan telah sesuai dengan kemajuan ilmu dan teknologi dan ataupun standar yang telah ditetapkan.

2). Dapat meningkatkan efisiensi pelayanan kesehatan. Peningkatan efisiensi yang dimaksudkan ini erat hubungannya dengan dapat dicegahnya pelayanan kesehatan yang dibawah standar dan ataupun yang berlebihan.

3). Dapat meningkatkan penerimaan masyarakat terhadap pelayanan kesehatan. Peningkatan penerimaan ini erat hubungannya dengan telah sesuainya pelayanan kesehatan dengan kebutuhan dan tuntutan pemakai jasa pelayanan.

4). Dapat melindungi penyelenggara pelayanan kesehatan dan kemungkinan timbulnya gugutan hukum. Pada saat ini sebagai akibat makin baiknya tingkat pendidikan masyarakat, maka kesadaran hukum masyarakat yang telah semakin meningkat. Dari uraian tersebut, dipahami bahwa terselenggaranya program menjaga mutu pelayanan kesehatan mempunyai peranan yang besar dalam melindungi penyelenggara pelayanan kesehatan dan meningkatkan kepuasan pasien.

\section{Pengukuran Mutu Pelayanan Kesehatan}

Pohan (2006), membuat kerangka pikir untuk mengukur mutu layanan kesehatan berdasarkan komponen mutu, meliputi:

\section{Standar struktur}

Standar struktur adalah standar yang menjelaskan peraturan sistem, kadangkadang disebut juga sebagai masukan atau struktur. Termasuk ke dalamnya adalah hubungan organisasi, misi organisasi, kewenangan, komitekomite, personel, peralatan, gedung, rekam medik, keuangan, perbekalan, obat, dan fasilitas. Standar struktur disebut juga sebagai rules of the game.

2. Standar proses

Standar proses adalah sesuatu yang menyangkut semua aspek pelaksanaan kegiatan pelayanan kesehatan, melakukan prosedur dan kebijaksanaan. Standar proses menjelaskan apa yang harus dilakukan, bagaimana melakukannya dan bagaimana sistem bekerja.

3. Standar keluaran

Standar keluaran adalah hasil akhir atau akibat dari pelayanan kesehatan. Standar keluaran akan menujukkan apakah pelayanan kesehatan akan berhasi atau gagal. Keluaran (outcome) adalah apa yang diharapkan akan terjadi sebagai hasil dari pelayanan kesehatan yang diselenggarakan dan terhadap apa keberhasilan tersebut akan diukur. Salah satu keluaran yang dimaksud dan dapat diukur adalah kepuasan pasien.

\section{Pengertian Kepuasan Pasien}

Kepuasan pasien adalah suatu tingkat perasaan pasien yang timbul sebagai akibat dari kinerja layanan kesehatan yang diperolehnya setelah pasien membandingkannya dengan apa yang diharapkannya, bahwa pasien akan merasa puas apabila kinerja layanan kesehatan yang diperolehnya sama atau melebihi harapannya dan sebaliknya ketidakpuasan atau perasaan kecewa akan muncul jika kinerja layanan kesehatan yang diperolehnya itu tidak sesuai dengan kinerjanya sendiri. Kepuasan pasien dapat mempengaruhi minat untuk kembali ke tempat yang sama. (Pohan, 2006).

Menurut Umar (2002) kepuasan pasien dibagi dua macam, yaitu: kepuasan fungsional dan kepuasan psikologikal. Kepuasan fungsional merupakan kepuasan yang diperoleh dari fungsi suatu 
produk yang dimanfaatkan, sedangkan kepuasan psikologikal merupakan kepuasan yang diperoleh dari atribut yang sifatnya tidak berwujud dari produk. Menurut Kotler (1997) kepuasan pasien adalah tingkat kepuasan seseorang setelah membandingkan kinerja atau hasil yang dirasakan dibandingkan dengan harapannya. Jadi kepuasan atau ketidakpuasan adalah kesimpulan dari interaksi antara harapan dan pengalaman sesudah memakai jasa atau pelayanan yang diberikan. Upaya untuk mewujudkan kepuasan pelanggan total bukanlah hal yang mudah, kepuasan pelanggan total tidak mungkin tercapai, sekalipun hanya untuk sementara waktu.

\section{Model Kepuasan Pasien}

Wostbook \& Really (1983) dalam Tjiptono (2012:349) berpendapat bahwa kepuasan pelanggan merupakan respon emosional terhadap pengelamanpengalaman berkaitan dengan produk jasa tertentu yang dibeli, gerai ritel, atau bahkan pola perilaku seperti perilaku berbelanja dan perilaku pembeli, serta pasar secara keseluruhan. Respon emosional dipicu oleh proses evaluasi kognitif yang membandingkan persepsi atau keyakinan terhadap objek.

Tindakan atau kondisi tertentu dengan nilai-nilai (atau kebutuhan, keinginan dan hasrat) individual. Mowen (1995) dalam Tjiptono, (2012:349-350) merumuskan kepuasan pelanggan sebagai sikap keseluruhan terhadap suatu barang atau jasa setelah perolehan (acquisition) dan pemakainya.

Dengan kata lain, kepuasan pelanggan merupakan penilaian purnabeli yang di hasilkan dari seleksi pembelian spesifikasi. Definisi ini dijabarkan ke dalam model kepuasan/ketidakpuasan pelanggan sebagaimana tersaji dalam gambar berikut:

$\begin{array}{lccc}\text { Gambar } & 2.1 & : & \text { Model } \\ \text { Kepuasan/Ketidakpuasan Pelanggan } & \end{array}$

Pengukuran Kepuasan Pasien
Pemantauan dan pengukuran terhadap kepuasan pelanggan telah menjadi hal yang sangat esensial bagi setiap perusahaan. Hal ini dikarenakan langkah tersebut dapat memberikan umpan balik dan memuaskan bagi keperluan pengembangan. Pada prinsipnya kepuasan pelanggan itu dapat diukur dengan berbagai macam metode dan teknik. Kolter (1994) dalam Tjiptono (2012:39-40) mengidentifikasi empat metode untuk mengukur kepuasan pelanggan, yaitu sebagai berikut:

a. Sistem keluhan dan saran Organisasi yang berpusat pada pelanggan (customer-centered) memberikan kesempatan yang luas kepada para pelanggannya untuk menyampaikan saran, kartu komentar, costumer hot lines dan lain-lain. Informasi-informasi ini dapat memberikan ide-ide dan masukan kepada perusahaan dan memungkinkan untuk bereaksi dengan yang timbul. Metode ini lebih fokus pada identifikasi masalah dan pengumpulan saran.

b. Ghost shooping Salah satu cara untuk membperoleh gambaran mengenai kepuasan pelanggan adalah dengan mempekerjakan beberapa orang (Ghost shooper) untuk berperan atau bersikap sebagai pembeli potensial terhadap produk perusahaan dan pesaing. Kemudian mereka melaporkan temuan temuannya dan pesaing berdasarkan pengalaman mereka dalam pembelian produk-produk tersebut. Selain itu pada ghost shooper juga. dapat mengamati cara penanganan setiap keluhan, baik oleh perusahaan yang bersangkutan maupun pesaingnya.

c. Lost customer analysis Perusahaan seyogyanya menghubungi para pelanggan yang telah berhenti membeli atau yang telah pindah pemasok agar dapat memahami mengapa hal itu terjadi. Bukan hanya exit intervew saja yang perlu, tetapi pemantauan customer loss rute menunjang penting, di mana peningkatan customer lose rute menunjukan kegagalan 
perusahaan dalam memuaskan pelanggannya.

d. Survei kepuasan pelanggan Umumnya penelitian mengenai kepuasan pelanggan dilakukan dengan penlitian survai. Baik dengan siurvai melalui pos, telepon maupun wawancara probadi melalui survai perusahaan akan memperoleh tenggapan dan umpan balik (feebeck) secara langsung dari pelanggan dan juga memberikan tanda (singal) positif bawha perusahaan menaruh perhatian terhadap para pelanggannya.

Tingkat kepuasan pelanggan sangat tergantung pada mutu suatu produk. Suatu produk dikatakan bermutu bagi seseorang jika produk tersebut dapat memenuhi kebutuhannya. Aspek mutu suatu produk dapat diukur. Pengukuran tingkat kepuasan erat hubungannya dengan mutu produk. Di samping itu, pengukuran aspek mutu bermanfaat bagi pimpinan bisnis, yaitu untuk mengetahui dengan baik bagaimana jalannya proses binis, mengetahui di mana harus melakukan perubahan dalam upaya melakukan perbaikan secara terus-menerus untuk memuaskan pelanggan, serta dapat bermanfaat unutk menentukan apakah perubahan yang dilakukan mengarah ke perbaikan (Yuliarmi dan Riyasa, 2012:16).

\section{Prinsip - Prinsip Dasar Kepuasan Pasien}

Yuliarmi dan Riyasa (2012:14) mengemukakan bahwa kepuasan pelanggan sangat tergantung pada persepsi dan harapan pelanggan. Sebuah perusahaan perlu mengetahui beberapa faktor yang mempengaruhi persepsi dan harapan pelanggan. Faktor-faktor yang mempengaruhi persepsi dan harapan pelanggan terhadap kualitas pelayanan diantaranya adalah sebagai berikut:

1) Kebutuhan dan keinginan, yaitu berkaitan dengan hal-hal yang dirasakan oleh pelanggan saat pelanggan sedang mencoba melakukan ternsaksi dengan perusahaan. Jika pada saat itu kebutuhan dan keinginan terhadap kualitas pelayanan kesehatan yang ditawarkan oleh rumah sakit sangat besar, maka harapan-harapan pelanggan yang berkaitan dengan kualitas produk dan layanan perusahaan akan tinggi pula, begitu juga sebaliknya.

2) Pengalaman masa lalu (terdahulu) ketika mengkonsumsi produk dan layanan, baik dari perusahaan maupun pesaing-pesaingnya.

3) Pengalaman teman-teman, cerita teman pelanggan tentang kualitas produk dan layanan perusahaan yang akan didapat oleh pelanggan.

4) Komunikasi melalui iklan dan pemasaran atau persepsi yang timbul dari image periklanan dan pemasaran yang dilakukan oleh perusahaan.

\section{Pengertian Word of Mouth (WOM)}

Word of Mouth Marketing adalah komunikasi tentang produk antara orangorang yang dianggap independen dari perusahaan. yang menyediakan produk. Komunikasi ini dilakukan dalam medium yang akan dianggap independen dari perusahaan. Komunikasi ini bisa saja berupa percakapan, atau hanya satu arah testimonial. Misalnya berbicara langsung, melalui telepon, e-mail, listgroup, atau sarana komunikasi lainnya (Silverman, 2001).

Menurut Kotler \& Keller (2012) Word of Mouth Communication (WOM) atau komunikasi dari mulut ke mulut merupakan proses komunikasi yang berupa pemberian rekomendasi baik secara individu maupun kelompok terhadap suatu produk atau jasa yang bertujuan untuk memberikan informasi secara personal.

Harrison Walker (2001) dalam Harris et al (2013) mendefinisikan komunikasi WOM sebagai komunikasi informal orang ke orang antara komunikator nonkomersial dan penerimanya berdasarkan merek, produk, organisasi, atau jasa. WOM ini dapat bermuatan positif atau negatif. WOM negatif bertujuan untuk merendahkan objek dalam komunikasi tersebut (Richins, 1983 dalam Harris et al , 2013).

West-brook (1987) dalam Pontevia et al (2008) memandang WOM sebagai fenomena post-pembelian yang mengandung komunikasi informal yang 
diarahkan kepada konsumen lain mengenai kepemilikan, kegunaan, atau karakteristik produk atau jasa. Pandangan ini juga senada dengan pandangan Sundaram et al (1998) dalam Pontevia et al (2008), yang mendefinisikan WOM sebagai bentuk komunikasi interpersonal di antara konsumen tentang pengalaman pribadi dengan produk atau perusahaan.

\section{Aturan Menjalankan Word of Mouth (WOM)}

Dari hal tersebut, terdapat persamaan mendasar mengenai pengertian WOM. Persamaan tersebut adalah WOM merupakan komunikasi antara oang-orang mengenai produk dan jasa secara independen (bukan mewakili perusahaan).

Menurut Sernovitz (2012), terdapat empat aturan yang harus dijalankan agar tercipta suatu WOM, yaitu:

a. Informasi dalam WOM dibuat menarik. Orang tidak suka dengan sesuatu yang membosankan. Berikan suatu hal yang membuat orang lain bisa membicarakan mengenai hal yang ingin di WOM-kan. Harus selalu memikirkan bagaimana cara agar orang mau menceritakan kembali apa yang ingin di WOM-kan.

b. WOM dibuat menjadi mudah disebarluaskan. WOM yang baik menggunakan pesan yang singkat dan jelas serta mudah disebarkan. Memulai WOM dengan hal - hal yang mudah diingat.

c. Lawan bicara saat komunikasi WOM dilakukan dibuat menjadi bahagia. Saat orang menjadi bahagia, mereka akan mau menyebarkan berita positif mengenai produk yang dijual. Orang tersebut akan mudah mengenang produk tersebut.

d. Harus mendapatkan respek dan kepercayaan dari lawan bicara saat menyebarkan informasi WOM. Tidak mendapatkan respek dan kepercayaan sama dengan tidak mendapatkan WOM. Orang- orang tidak akan berkata positif mengani hal yang tidak mereka percayai.

\section{Dimensi Word of Mouth (WOM)}

Menurut Sernovitz (2012), terdapat tiga hal dasar yang mendorong orang melakukan percakapan WOM:

a. Orang menyukai produk yang dikonsumsinya. Karena mereka suka, para konsumen akan tertarik untuk membahas produk tersebut. Hal ini menjadi alasan untuk diri mereka berbicara mengenai produk yang dikonsumsinya.

b. Orang- orang merasa baik saat bisa berbicara dengan sesamanya. Pembicaraan mengenai WOM tidak hanya sebatas fitur dari produk namun lebih ke masalah emosi. Saat melakukan WOM, orang bisa terlihat lebih pintar, membantu orang lain, dan merasa dirinya menjadi penting.

c. Komunikasi WOM membuat orang merasa terhubung dalam suatu kelompok. Membicarakan produk yang digunakan dalam kelompok tersebut akan membuat orang merasa dalam suatu kelompok yang sama. Keinginan untuk menjadi bagian dari kelompok ini yang mendorong orang melakukan WOM.

\section{Penelitian Terdahulu}

Penelitian terdahulu yang relevan dengan penelitian ini adalah penelitian yang pernah dilakukan oleh :

1. Indrianti retno dwi (2010)," Analisis pengaruh tingkat kualitas pelayanan jasa Puskesmas terhadap kepuasan pasien di Puskesmas Gunungpati Semarang". Penelitian ini bertujuan untuk menguji pengaruh tingkat kualitas pelayanan jasa puskesmas terhadap kepuasan pasien. Penelitian ini menggunakan metode analisis kuantitatif dengan menggunakan uji validitas dan reabilitas, uji asumsi klasik, uji F, koefisien determinasi, uji $\mathrm{T}$, dan analisis regresi berganda. Sampel yang di gunakan berjumlah 100 responden. Metode pengambilan sampel menggunakan purposive sampling. Populasi dalam penelitian ini 1819 pasien. Hasil penelitian di dapatkan bahwa dengan menggunakan 
metode regresi berganda dapat di simpulkan bahwa variable bukti langsung berpengaruh positif dan signifikan terhadap kepuasan konsumen dengan nilai signifikansi ( $\mathrm{P}$ Value) sebesar $\quad 0,003<0,05$. Sedangkan kehandalan berpengaruh positif tetapi tidak signifikan terhadap kepuasan konsumen dengan nilai signifikansi (PValue)sebesar0,440>0,05. Jaminan berpengaruh positif tetapi tidak signifikansi terhadap kepuasan konsumen dengan nilai signifikansi ( $\mathrm{P}$ Value) sebesar $0,164<0,05$. Daya tanggap berpengaruh positif tetapi tidak signifikan terhadap kepuasan konsumen dengan nilai signifikasni (PValue) sebesar 0,339>0,05.Untuk empati tidak berpengaruh positif dan tidak signifikan terhadap kepuasankonsumen dengan nilai signifikansi (P Value) sebesar $0,623>0,05$. Secara simultanbukti langsung, kehandalan, jaminan, daya tanggap dan empati berpengaruhsignifikan terhadap kepuasan konsumen dengan $\mathrm{F}$ hitung sebesar 11,186 denganangka signifikansi ( $\mathrm{P}$ Value) sebesar $0,000<0,05$. Koefisien determinasi yangdihasilkan adalah sebesar 0,34 yang berarti 34 persen perubahan variabel kepuasankonsumen dijelaskan oleh perubahan variabel bukti langsung, kehandalan, jaminan, daya tanggap dan empati secara bersama-sama. Persamaan nya pada penelitian ini adalah metode yang di gunakan adalah metode kuantitatif dan variable terikatnya kepuasan pasien, sedangkan perbedaannya variable bebasnya yaitu tingkat kualitas jasa pelayanan puskesmas serta metode yang di gunakan adalah Purposive Sampling.

2. Rustam Effendi (2013), "Hubungan mutu pelayanan kesehatan dengan kepuasan pasien rawat jalan di Puskesmas Aeng towa Kabupaten Takalar". Penelitian ini bertujuan untuk mengetahui hubungan mutu pelayanan kesehatan dengan kepuasan pasien di Puskesmas Towa Kabupaten Takalar. Penelitian ini menggunakan metode kuantitatif dengan pendekatan crossectional. Metode penarikan sampel adalah accidental sampling. Sampel yang di gunakan berjumlah 100 orang. Hasil penelitian menunjukkan bahwa ada hubungan antara kenyamanan, ketepatan waktu dan hubungan antar manusia dengan kepuasan pasien di puskesmas Aeng Towa Kabupaten Takalar tahun 2013. Melalui penelitian ini, sebaiknya pihak puskesmas lebihmeningkatkan kenyamanan pada bagian kondisi ruang tunggu yang masih agak berdesakan, kebersihan dan kelengkapan peralatan, dan kondisi toilet yang masih kurang baik, puskesmas harus lebih meningkatkanketepatan waktukarena masih ada pasien yang mengeluhkan ketepatan waktu tenaga kesehatan dan pelayanan yang masih lambat dan berbelit-belit serta puskesmas harus lebih meningkatkan hubungan tenaga kesehatan dengan pasien. Persamaanya dengan penelitian ini ada variable terikatnya kepuasan pasien serta metode yang di gunakan adalah metode pendekatan kuantitatif, sedangkan perbedaannya variable bebasnya yaitu mutu pelayanan serta metode penarikan sampel adalah accidental sampling.

3. Rahmalani Yonika. 2018. Pengaruh Kualitas Pelayanan Terhadap Word Of Mouth Dengan Kepuasan Konsumen Sebagai Variabel Intervening (Studi Pada Wedding Organizer " Rahma Gunter " Bandar Lampung). Penelitian ini bertujuan untuk mengetahui kualitas layanan berpengaruh terhadap Word of Mouth (WOM) dengan kepuasan konsumen sebagai pemediasi pada wedding organizer "Rahma Gunter" Bandar Lampung. Jumlah sampel pada penelitian ini sebanyak 100 orang konsumen, dengan teknik sampel purposive sampling yakni konsumen yang mengetahui pelayanan pada Wedding Orginizer "Rahma Gunter". Penelitian ini memperlihatkan bahwa kualitas layanan secara parsial memiliki pengaruh positif dan signifikan terhadap kepuasan pelanggan, kualitas 
pelayanan berpengaruh positif dan signifikan terhadap Word Of Mouth, serta kualitas layanan dan kepuasan konsumen memiliki pengaruh positif dan signifikan terhadap Word Of Mouth (WOM), pada wedding organizer "Rahma Gunter" Bandar Lampung.

Kerangka Konseptual Dan Hipotesis

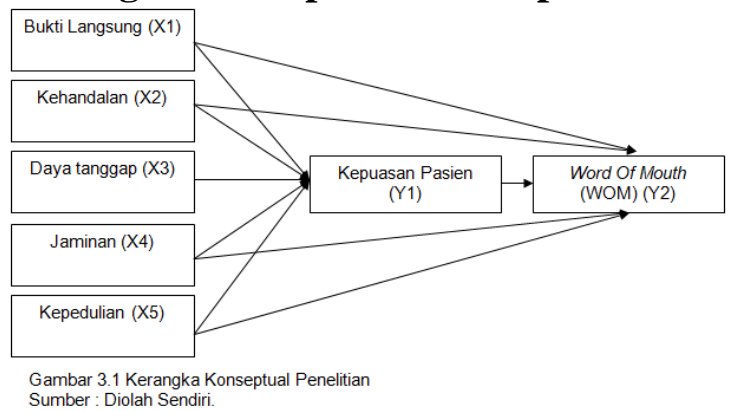

\section{Hipotesis Penelitian}

1. Bukti Langsung berpengaruh signifikan terhadap Kepuasan Pasien di Kabupaten Tabalong.

2. Kehandalan berpengaruh signifikan terhadap Kepuasan Pasien di Kabupaten Tabalong.

3. Daya tanggap berpengaruh signifikan terhadap Kepuasan Pasien di Kabupaten Tabalong.

4. Jaminan berpengaruh signifikan terhadap Kepuasan Pasien di Kabupaten Tabalong.

5. Kepedulian berpengaruh signifikan terhadap Kepuasan Pasien di Kabupaten Tabalong.

6. Bukti Langsung berpengaruh signifikan terhadap Word Of Mouth (MOM) di Kabupaten Tabalong.

7. Kehandalan berpengaruh signifikan terhadap Word Of Mouth (MOM) di Kabupaten Tabalong.

8. Daya tanggap berpengaruh signifikan terhadap Word Of Mouth (MOM) di Kabupaten Tabalong.

9. Jaminan berpengaruh signifikan terhadap Word Of Mouth (MOM) di Kabupaten Tabalong.

10. Kepedulian berpengaruh signifikan terhadap Word Of Mouth (MOM) di Kabupaten Tabalong.

11. Kepuasan Pasien berpengaruh signifikan terhadap Word Of Mouth (MOM) di Kabupaten Tabalong

\section{Motode Penelitian \\ Lokasi Penelitian}

Adapun lokasi dan waktu penelitian ini adalah pada Puskesmas di Kabupaten Tabalong Puskesmas Kelua,Kabupaten Tabalong Kalimantan Selatan.

\section{Populasi}

Populasi Sugiyono, (2006:81) adalah wilayah generalisasi yang terdiri atas obyek/subyek yang mempunyai kualitas dan karakteristik tertentu yang ditetapkan untuk dipelajari dan kemudian ditarik kesimpulannya. Populasi pada penelitian ini adalah seluruh pasien Puskesmas di Kabupaten Tabalong. yang berjumlah rata-rata setiap hari berjumlah 1200 (seribu dua ratus) orang.

Sampel

Pengambilan sampel penelitian harus seksama dan memenuhi aturan-aturan dalam pemilihan sampel. Sebagai acuan apabila subyek kurang dari 100 maka lebih baik diambil seluruhnya, sehingga penelitiannya merupakan penelitian populasi Arikunto, (2006:57).

Populasi dalam penelitian ini lebih dari 100 orang, maka untuk mempersingkat waktu dan dana penelitian untuk itu dilakukan pengambilan sampel secara acak berdasarkan rumus Slovin (dalam Umar, 2010: 120).seperti di bawah ini :

$$
\mathbf{n}=\frac{\mathrm{N}}{1+\mathrm{N} \text { e2 }}
$$

di mana:

$$
\begin{array}{ll}
1 & =\text { Konstanta } \\
\mathrm{n} & =\text { Ukuran sampel } \\
\mathrm{N} & =\text { Ukuran populasi } \\
\mathrm{e} 2 & =\text { Kelonggaran ketidaktelitian } \\
& \text { karena kesalahan pengambilan } \\
& \text { sampel yang dapat ditolerir }
\end{array}
$$

Diketahui :

1 = konstanta

$\mathrm{n}=$ ukuran sampel

$\mathrm{N}=1200$

$\mathrm{e} 2=5 \%$

$$
\mathrm{N}=\frac{1200}{1+1200\left(0,05^{2}\right.}=\frac{1200}{1+3}=\frac{1200}{4}=300
$$


Berdasarkan hasil perhitungan diatas menggunakan taraf kepercayaan $95 \%$ maka sampel dalam penelitian ini berjumlah 300 (tiga ratus) orang Pasien Puskesmas di Kabupaten Tabalong.

\section{Intrumen Penelitian}

Pengukuran variabel dalam penelitian ini menggunakan skala likert. Skala likert digunakan untuk mengukur sikap, pendapat, dan persepsi seseorang atau sekelompok orang tentang fenomena sosial. Skala ini meminta responden menunjukan tingkat persetujuan atau ketidaksetujuannya terhadap serangkaian pertanyaan tentang suatu objek (Sugiyono, 2012). Untuk masing-masing responden mempunyai 5 alternatif jawaban (Skala Likert). Masingmasing prioritas dari kelima point tersebut, yaitu:
1. Sangat setuju (SS)
: diberi nilai 5
2. Setuju (S)
: diberi nilai
4
3. Ragu Ragu (R)
: diberi nilai 3
4. Tidak setuju (TS)
: diberi nilai 2

5. Sangat tidak setuju (STS) : diberi nilai 1

\section{Hasil Dan Pembahasan}

Uji Validitas dan Reliabilitas

a. Uji Validitas Variabel Bukti Fisik

Variabel Bukti Fisik terdiri atas 5 item pertanyaan, dimana seluruh item pertanyaan nilai Pearson Correlation untuk masing masing pertanyaan akan dibandingkan dengan $r$ syarat sebasar 0.3 .

Tabel. 5.30

Hasil Analisis Angket Untuk Validitas Variabel Bukti Fisik

\begin{tabular}{|c|c|c|c|c|}
\hline \multicolumn{2}{|r|}{ Variabel } & \multicolumn{2}{|c|}{ TotalX1 Syarat } & Keterangan \\
\hline $\mathrm{X} 1.1$ & $\begin{array}{c}\text { Pearson } \\
\text { Correlation }\end{array}$ & 0.751 & 0.3 & Valid \\
\hline $\mathrm{X} 1.2$ & $\begin{array}{c}\text { Pearson } \\
\text { Correlation }\end{array}$ & 51 & 0.3 & Valid \\
\hline $\mathrm{X} 1.3$ & $\begin{array}{c}\text { Pearson } \\
\text { Correlation }\end{array}$ & 0.797 & 0.3 & Valid \\
\hline
\end{tabular}

Sumber : Hasil pengolahan data pada Lampiran 3

Berdasarkan Tabel 5.30 diatas maka menunjukkan bahwa semua item pertanyaan pada variabel X1 (Bukti Fisik ) memiliki nilai korelasi lebih besar dari $\mathrm{r}_{\text {syarat }}$ dan dapat disimpulkan bahwa semua item pertanyaan adalah valid. Maka dapat disimpulkan bahwa semua butir pertanyaan atau pernyataan tersebut dapat dibuktikan terhadap variabel Bukti Fisik .

\section{b. Uji Validitas Variabel Kehandalan}

Variabel Kehandalan terdiri atas 3 item pertanyaan, dimana seluruh item pertanyaan nilai Pearson Correlation untuk masing masing pertanyaan akan dibandingkan dengan $r$ syarat sebasar 0.3.

Tabel. 5.31

Hasil Analisis Angket Untuk Validitas Variabel Kehandalan

\begin{tabular}{|c|c|c|c|c|}
\hline \multicolumn{1}{|c|}{ Variabel } & $\begin{array}{c}\text { TotalX } \\
1\end{array}$ & $\begin{array}{c}\text { Syara } \\
\mathrm{t}\end{array}$ & $\begin{array}{c}\text { Keteranga } \\
\mathrm{n}\end{array}$ \\
\hline $\mathrm{X} 2$. & $\begin{array}{c}\text { Pearson } \\
\text { Correlatio } \\
\mathrm{n}\end{array}$ & 0.720 & 0.3 & Valid \\
\hline $\mathrm{X} 2$. & $\begin{array}{c}\text { Pearson } \\
\text { Correlatio } \\
2\end{array}$ & 0.751 & 0.3 & Valid \\
\hline $\mathrm{X} 2$. & $\begin{array}{c}\text { Pearson } \\
\text { Correlatio } \\
3\end{array}$ & 0.774 & 0.3 & Valid \\
\hline
\end{tabular}

Sumber : Hasil pengolahan data pada Lampiran3

Berdasarkan Tabel 5.31 diatas maka menunjukkan bahwa semua item pertanyaan pada variabel X2 Kehandalan memiliki nilai korelasi lebih besar dari $r_{\text {syarat }}$ dan dapat disimpulkan bahwa semua item pertanyaan adalah valid. Maka dapat disimpulkan bahwa semua butir pertanyaan atau pernyataan tersebut dapat dibuktikan terhadap variabel Kehandalan .

\section{c. Uji Validitas Variabel Daya tanggap}

Variabel Daya tanggap terdiri atas 3 item pertanyaan, dimana seluruh item pertanyaan nilai Pearson Correlation untuk masing masing pertanyaan akan dibandingkan dengan $r$ syarat sebasar 0.3.

Tabel. 5.32

Hasil Analisis Angket Untuk Validitas Variabel Daya tanggap

\begin{tabular}{|c|c|c|c|c|}
\hline \multicolumn{2}{|c|}{ Variabel } & $\begin{array}{c}\text { TotalX } \\
1\end{array}$ & $\begin{array}{c}\text { Syara } \\
\mathrm{t}\end{array}$ & $\begin{array}{c}\text { Keteranga } \\
\mathrm{n}\end{array}$ \\
\hline $\mathrm{X} 3$. & $\begin{array}{c}\text { Pearson } \\
\text { Correlatio } \\
\mathrm{n}\end{array}$ & 0.775 & 0.3 & Valid \\
\hline
\end{tabular}




\begin{tabular}{|c|c|c|c|c|}
\hline $\begin{array}{c}\text { X3 } \\
2\end{array}$ & $\begin{array}{c}\text { Pearson } \\
\text { Correlatio } \\
n\end{array}$ & 0.756 & 0.3 & Valid \\
\hline $\begin{array}{c}\text { X3. } \\
3\end{array}$ & $\begin{array}{c}\text { Pearson } \\
\text { Correlatio } \\
n\end{array}$ & 0.774 & 0.3 & Valid \\
\hline
\end{tabular}

Sumber : Hasil pengolahan data pada Lampiran3

Berdasarkan Tabel 5.32 diatas maka menunjukkan bahwa semua item pertanyaan pada variabel X3 Daya tanggap memiliki nilai korelasi lebih besar dari $\mathrm{r}_{\text {syarat }}$ dan dapat disimpulkan bahwa semua item pertanyaan adalah valid. Maka dapat disimpulkan bahwa semua butir pertanyaan atau pernyataan tersebut dapat dibuktikan terhadap variabel Daya tanggap.

\section{d. Uji Validitas Variabel Jaminan}

Variabel Jaminan terdiri atas 3 item pertanyaan, dimana seluruh item pertanyaan nilai Pearson Correlation untuk masing masing pertanyaan akan dibandingkan dengan $r$ syarat sebasar 0.3 .

Tabel. 5.33

Hasil Analisis Angket Untuk Validitas Variabel Jaminan

\begin{tabular}{|c|c|c|c|c|}
\hline \multicolumn{1}{|c|}{ Variabel } & $\begin{array}{c}\text { TotalX } \\
1\end{array}$ & $\begin{array}{c}\text { Syara } \\
\mathrm{t}\end{array}$ & $\begin{array}{c}\text { Keteranga } \\
\mathrm{n}\end{array}$ \\
\hline $\begin{array}{c}\mathrm{X} 4 . \\
1\end{array}$ & $\begin{array}{c}\text { Pearson } \\
\text { Correlatio } \\
\mathrm{n}\end{array}$ & 0.752 & 0.3 & Valid \\
\hline $\mathrm{X} 4$. & $\begin{array}{c}\text { Pearson } \\
\text { Correlatio } \\
\mathrm{n}\end{array}$ & 0.767 & 0.3 & Valid \\
\hdashline $\mathrm{X} 4$. & $\begin{array}{c}\text { Pearson } \\
\text { Correlatio } \\
3\end{array}$ & 0.791 & 0.3 & Valid \\
\hline
\end{tabular}

Sumber : Hasil pengolahan data pada Lampiran3

Berdasarkan Tabel 5.33 diatas maka menunjukkan bahwa semua item pertanyaan pada variabel X5 Jaminan memiliki nilai korelasi lebih besar dari $\mathrm{r}_{\text {syarat }}$ dan dapat disimpulkan bahwa semua item pertanyaan adalah valid. Maka dapat disimpulkan bahwa semua butir pertanyaan atau pernyataan tersebut dapat dibuktikan terhadap variabel Jaminan.

\section{e. Uji Validitas Variabel Kepedulian}

Variabel Kepedulian terdiri atas 3 item pertanyaan, dimana seluruh item pertanyaan nilai Pearson Correlation untuk masing masing pertanyaan akan dibandingkan dengan $r$ syarat sebasar 0.3 .

Tabel. 5.34

Hasil Analisis Angket Untuk Validitas Variabel Kepedulian

\begin{tabular}{|c|c|c:c|c|}
\hline \multicolumn{1}{|c|}{ Variabel } & $\begin{array}{c}\text { TotalX } \\
1\end{array}$ & $\begin{array}{c}\text { Syara } \\
\mathrm{t}\end{array}$ & $\begin{array}{c}\text { Keteranga } \\
\mathrm{n}\end{array}$ \\
\hline $\mathrm{X} 5$. & $\begin{array}{c}\text { Pearson } \\
\text { Correlatio } \\
\mathrm{n}\end{array}$ & 0.738 & 0.3 & Valid \\
\hline $\mathrm{X} 5$. & $\begin{array}{c}\text { Pearson } \\
\text { Correlatio } \\
\mathrm{n}\end{array}$ & 0.765 & 0.3 & Valid \\
\hdashline $\mathrm{X} 5$. & $\begin{array}{c}\text { Pearson } \\
\text { Correlatio } \\
\mathrm{n}\end{array}$ & 0.820 & 0.3 & Valid \\
\hline
\end{tabular}

Sumber : Hasil pengolahan data pada Lampiran3

Berdasarkan Tabel 5.34 diatas maka menunjukkan bahwa semua item pertanyaan pada variabel X5 Kepedulian memiliki nilai korelasi lebih besar dari $\mathbf{r}_{\text {syarat }}$ dan dapat disimpulkan bahwa semua item pertanyaan adalah valid. Maka dapat disimpulkan bahwa semua butir pertanyaan atau pernyataan tersebut dapat dibuktikan terhadap variabel Kepedulian.

\section{f. Uji Validitas Variabel Kepuasan Pasien (Z)}

Variabel Kepuasan Pasien terdiri atas 3 item pertanyaan, dimana seluruh item pertanyaan nilai Pearson Correlation untuk masing masing pertanyaan akan dibandingkan dengan $r$ syarat sebasar 0.3.

Tabel. 5.35

Hasil Analisis Angket Untuk Validitas Variabel Kepuasan Pasien

\begin{tabular}{|c|c|c|c|c|}
\hline \multicolumn{2}{|c|}{ Variabel } & $\begin{array}{c}\text { TotalX } \\
1\end{array}$ & $\underset{t}{\text { Syara }}$ & $\begin{array}{c}\text { Keteranga } \\
n\end{array}$ \\
\hline $\begin{array}{c}\mathrm{Y} 1 . \\
1\end{array}$ & $\begin{array}{c}\text { Pearson } \\
\text { Correlatio } \\
n\end{array}$ & 0.758 & 0.3 & Valid \\
\hline $\begin{array}{c}\text { Y1. } \\
2\end{array}$ & $\begin{array}{c}\text { Pearson } \\
\text { Correlatio } \\
n\end{array}$ & 0.721 & 0.3 & Valid \\
\hline $\begin{array}{c}\mathrm{Y} 1 . \\
3\end{array}$ & $\begin{array}{c}\text { Pearson } \\
\text { Correlatio } \\
n\end{array}$ & 0.729 & 0.3 & Valid \\
\hline $\begin{array}{c}\mathrm{Y} 1 . \\
4\end{array}$ & $\begin{array}{c}\text { Pearson } \\
\text { Correlatio } \\
n\end{array}$ & 0.741 & 0.3 & Valid \\
\hline
\end{tabular}

Sumber : Hasil pengolahan data pada Lampiran 3 
Berdasarkan Tabel 5.35 diatas maka menunjukkan bahwa semua item pertanyaan pada variabel Y1 (Kepuasan Pasien ) memiliki nilai korelasi lebih besar dari $\mathrm{r}_{\text {syarat }}$ dan dapat disimpulkan bahwa semua item pertanyaan adalah valid. Maka dapat disimpulkan bahwa semua butir pertanyaan atau pernyataan tersebut dapat dibuktikan terhadap variabel Kepuasan Pasien .

\section{g. Uji Validitas Variabel Word of Mouth (WOM)}

Variabel Word of Mouth (WOM) terdiri atas 3 item pertanyaan, dimana seluruh item pertanyaan nilai Pearson Correlation untuk masing masing pertanyaan akan dibandingkan dengan $r$ syarat sebasar 0.3.

\section{Tabel. 5.36}

\section{Hasil Analisis Angket Untuk Validitas} Variabel Word of Mouth (WOM)

\begin{tabular}{|c|c|c:c:c|}
\hline Variabel & $\begin{array}{c}\text { TotalX } \\
1\end{array}$ & $\begin{array}{c}\text { Syara } \\
\mathrm{t}\end{array}$ & $\begin{array}{c}\text { Keteranga } \\
\mathrm{n}\end{array}$ \\
\hline $\mathrm{Y} 2$. & $\begin{array}{c}\text { Pearson } \\
\text { Correlatio } \\
\mathrm{n}\end{array}$ & 0.778 & 0.3 & Valid \\
\hline $\mathrm{Y} 2$. & $\begin{array}{c}\text { Pearson } \\
\text { Correlatio } \\
2\end{array}$ & 0.647 & 0.3 & Valid \\
\hline $\mathrm{Y} 2$. & $\begin{array}{c}\text { Pearson } \\
\text { Correlatio } \\
3\end{array}$ & 0.777 & 0.3 & Valid \\
\hline
\end{tabular}

Sumber : Hasil pengolahan data pada Lampiran 3

Berdasarkan Tabel 5.36 diatas maka menunjukkan bahwa semua item pertanyaan pada variabel Y2.2 (Word of Mouth (WOM)) memiliki nilai korelasi lebih besar dari $\mathrm{r}_{\text {syarat }}$ dan dapat disimpulkan bahwa semua item pertanyaan adalah valid. Maka dapat disimpulkan bahwa semua butir pertanyaan atau pernyataan tersebut dapat dibuktikan terhadap variabel Word of Mouth (WOM) .

\section{Uji Realibilitas Variabel}

Variabel Bukti Fisik terdiri atas 4 item pertanyaan, Kehandalan terdiri atas 5 item pertanyaan, Kepuasan Pasienterdiri atas 3 item pertanyaan, Word of Mouth (WOM) terdiri atas 3 item pertanyaan dimana setiap item pertanyaan akan diuji tingkat Realibitas sebelum dilakukan pengujian terhadap hipotesa
a. Uji Realibilitas Variabel Bukti Fisik

Uji Reliabilitas dilakukan dengan tujuan untuk menguji sejauh mana alat pengukur dapat diandalkan atau dipercaya. Dalam Penelitian ini nilaiu reliabilitas suatu instrumen diterima jika memiliki Alpha Cronbach minimal 0,6.

Tabel 5.37

Hasil Uji Reabilitas Variabel Bukti Fisik

\begin{tabular}{|c|c|c|c|c|}
\hline $\begin{array}{c}\text { Item } \\
\text { pertany } \\
\text { aan }\end{array}$ & $\begin{array}{l}\text { Cronbach's } \\
\text { Alpha if Item } \\
\text { Deleted }\end{array}$ & $\begin{array}{l}\text { Sy } \\
\text { ar } \\
\text { at }\end{array}$ & $\begin{array}{l}\text { Alpha } \\
> \\
\text { Syarat }\end{array}$ & $\begin{array}{c}\text { Kete } \\
\text { rang } \\
\text { an }\end{array}$ \\
\hline X1.1 & 0.773 & $\begin{array}{c}0 . \\
6\end{array}$ & $\begin{array}{c}\text { Terbu } \\
\text { kti }\end{array}$ & $\begin{array}{c}\text { Reali } \\
\text { bel }\end{array}$ \\
\hline X1.2 & 0.788 & $\begin{array}{c}0 . \\
6\end{array}$ & $\begin{array}{c}\text { Terbu } \\
\text { kti }\end{array}$ & $\begin{array}{c}\text { Reali } \\
\text { bel }\end{array}$ \\
\hline X1.3 & 0.678 & $\begin{array}{l}0 . \\
6\end{array}$ & $\begin{array}{c}\text { Terbu } \\
\text { kti }\end{array}$ & $\begin{array}{c}\text { Reali } \\
\text { bel }\end{array}$ \\
\hline
\end{tabular}

Sumber : Hasil pengolahan data pada Lampiran 4

Dari hasil analisis data yang disebarkan maka terbukti bahwa seluruh item pertanyaan adalah Reliabel karena memiliki Alpha Cronbach lebih besar dari 0,6 .

\section{b. Uji Realibilitas Variabel Kehandalan}

Uji Reliabilitas dilakukan dengan tujuan untuk menguji sejauh mana alat pengukur dapat diandalkan atau dipercaya. Dalam Penelitian ini nilaiu reliabilitas suatu instrumen diterima jika memiliki Alpha Cronbach minimal 0,6.

\section{Tabel 5.38 \\ Hasil Uji Reabilitas Variabel Kehandalan}

\begin{tabular}{|c|c|c|c|c|}
\hline $\begin{array}{c}\text { Item } \\
\text { pertany } \\
\text { aan }\end{array}$ & $\begin{array}{l}\text { Cronbach's } \\
\text { Alpha if Item } \\
\text { Deleted }\end{array}$ & $\begin{array}{l}\text { Sy } \\
\text { ar } \\
\text { at }\end{array}$ & $\begin{array}{l}\text { Alpha } \\
> \\
\text { Syarat }\end{array}$ & $\begin{array}{l}\text { Kete } \\
\text { rang } \\
\text { an }\end{array}$ \\
\hline X2.1 & 0.762 & $\begin{array}{l}0 . \\
6\end{array}$ & $\begin{array}{c}\text { Terbu } \\
\text { kti }\end{array}$ & $\begin{array}{c}\text { Reali } \\
\text { bel }\end{array}$ \\
\hline X2.2 & 0.701 & $\begin{array}{c}0 . \\
6\end{array}$ & $\begin{array}{c}\text { Terbu } \\
\text { kti }\end{array}$ & $\begin{array}{c}\text { Reali } \\
\text { bel }\end{array}$ \\
\hline $\mathrm{X} 2.3$ & 0.651 & $\begin{array}{c}0 . \\
6\end{array}$ & $\begin{array}{c}\text { Terbu } \\
\text { kti }\end{array}$ & $\begin{array}{c}\text { Reali } \\
\text { bel }\end{array}$ \\
\hline
\end{tabular}

Sumber : Hasil pengolahan data pada Lampiran 4

Dari hasil analisis data yang disebarkan maka terbukti bahwa seluruh item pertanyaan adalah Reliabel karena 
memiliki Alpha Cronbach lebih besar dari 0,6 .

\section{c. Uji Realibilitas Variabel Daya tanggap}

Uji Reliabilitas dilakukan dengan tujuan untuk menguji sejauh mana alat pengukur dapat diandalkan atau dipercaya. Dalam Penelitian ini nilaiu reliabilitas suatu instrumen diterima jika memiliki Alpha Cronbach minimal 0,6.

Tabel 5.39

Hasil Uji Reabilitas Variabel Daya tanggap

\begin{tabular}{|ccccc|}
\hline $\begin{array}{c}\text { Item } \\
\text { pertany } \\
\text { aan }\end{array}$ & $\begin{array}{c}\text { Cronbach's } \\
\text { Alpha if Item } \\
\text { Deleted }\end{array}$ & $\begin{array}{c}\text { Sy } \\
\text { ar } \\
\text { at }\end{array}$ & $\begin{array}{c}\text { Alpha } \\
\text { Syarat }\end{array}$ & $\begin{array}{c}\text { Kete } \\
\text { rang } \\
\text { an }\end{array}$ \\
\hline X3.1 & 0.731 & $\begin{array}{c}0 . \\
6\end{array}$ & $\begin{array}{c}\text { Terbu } \\
\text { kti }\end{array}$ & $\begin{array}{c}\text { Reali } \\
\text { bel }\end{array}$ \\
X3.2 & 0.774 & $\begin{array}{c}0 . \\
6\end{array}$ & $\begin{array}{c}\text { Terbu } \\
\text { kti } \\
\text { Reali } \\
\text { bel }\end{array}$ & $\begin{array}{c}\text { Terbu } \\
\text { Reali } \\
\text { X3.3 }\end{array}$ \\
& 0.738 & 6 & kti & bel \\
\hline
\end{tabular}

Sumber : Hasil pengolahan data pada Lampiran 4

Dari hasil analisis data yang disebarkan maka terbukti bahwa seluruh item pertanyaan adalah Reliabel karena memiliki Alpha Cronbach lebih besar dari 0,6 .

\section{d. Uji Realibilitas Variabel Jaminan}

Uji Reliabilitas dilakukan dengan tujuan untuk menguji sejauh mana alat pengukur dapat diandalkan atau dipercaya. Dalam Penelitian ini nilaiu reliabilitas suatu instrumen diterima jika memiliki Alpha Cronbach minimal 0,6.

Tabel 5.40

Hasil Uji Reabilitas Variabel Jaminan

\begin{tabular}{|ccccc|}
\hline $\begin{array}{c}\text { Item } \\
\text { pertany } \\
\text { aan }\end{array}$ & $\begin{array}{c}\text { Cronbach's } \\
\text { Alpha if Item } \\
\text { Deleted }\end{array}$ & $\begin{array}{c}\text { Sy } \\
\text { ar } \\
\text { at }\end{array}$ & $\begin{array}{c}\text { Alpha } \\
> \\
\text { Syarat }\end{array}$ & $\begin{array}{c}\text { Kete } \\
\text { rang } \\
\text { an }\end{array}$ \\
\hline X4.1 & 0.785 & $\begin{array}{c}0 . \\
6\end{array}$ & $\begin{array}{c}\text { Terbu } \\
\text { kti }\end{array}$ & $\begin{array}{c}\text { Reali } \\
\text { bel }\end{array}$ \\
X4.2 & 0.768 & $\begin{array}{c}0 . \\
6\end{array}$ & $\begin{array}{c}\text { Terbu } \\
\text { kti }\end{array}$ & $\begin{array}{c}\text { Reali } \\
\text { bel }\end{array}$ \\
X4.3 & 0.708 & $\begin{array}{c}\text { Terbu } \\
6\end{array}$ & $\begin{array}{c}\text { Reali } \\
\text { kti }\end{array}$ & bel \\
\hline
\end{tabular}

Sumber : Hasil pengolahan data pada Lampiran 4

Dari hasil analisis data yang disebarkan maka terbukti bahwa seluruh item pertanyaan adalah Reliabel karena memiliki Alpha Cronbach lebih besar dari 0,6 .

\section{e. Uji Realibilitas Variabel Kepedulian}

Uji Reliabilitas dilakukan dengan tujuan untuk menguji sejauh mana alat pengukur dapat diandalkan atau dipercaya. Dalam Penelitian ini nilaiu reliabilitas suatu instrumen diterima jika memiliki Alpha Cronbach minimal 0,6.

Tabel 5.41

Hasil Uji Reabilitas Variabel Kepedulian

\begin{tabular}{|ccccc|}
\hline $\begin{array}{c}\text { Item } \\
\text { pertany } \\
\text { aan }\end{array}$ & $\begin{array}{c}\text { Cronbach's } \\
\text { Alpha if Item } \\
\text { Deleted }\end{array}$ & $\begin{array}{c}\text { Sy } \\
\text { ar } \\
\text { at }\end{array}$ & $\begin{array}{c}\text { Alpha } \\
> \\
\text { Syarat }\end{array}$ & $\begin{array}{c}\text { Kete } \\
\text { rang } \\
\text { an }\end{array}$ \\
\hline X5.1 & 0.836 & $\begin{array}{c}0 . \\
6\end{array}$ & $\begin{array}{c}\text { Terbu } \\
\text { kti }\end{array}$ & $\begin{array}{c}\text { Reali } \\
\text { bel }\end{array}$ \\
X5.2 & 0.801 & $\begin{array}{c}0 . \\
6\end{array}$ & $\begin{array}{c}\text { Terbu } \\
\text { kti }\end{array}$ & $\begin{array}{c}\text { Reali } \\
\text { bel }\end{array}$ \\
X5.3 & 0.662 & $\begin{array}{c}0 . \\
\text { Terbu } \\
\text { kti }\end{array}$ & $\begin{array}{c}\text { Reali } \\
\text { bel }\end{array}$ \\
\hline
\end{tabular}

Sumber : Hasil pengolahan data pada Lampiran 4

Dari hasil analisis data yang disebarkan maka terbukti bahwa seluruh item pertanyaan adalah Reliabel karena memiliki Alpha Cronbach lebih besar dari 0,6 .

\section{f. Uji Realibilitas Variabel Kepuasan Pasien}

Uji Reliabilitas dilakukan dengan tujuan untuk menguji sejauh mana alat pengukur dapat diandalkan atau dipercaya. Dalam Penelitian ini nilaiu reliabilitas suatu instrumen diterima jika memiliki Alpha Cronbach minimal 0,6.

Tabel 5.42

Hasil Uji Reabilitas Variabel Kepuasan Pasien

\begin{tabular}{|ccccc|}
\hline $\begin{array}{c}\text { Item } \\
\text { pertany } \\
\text { aan }\end{array}$ & $\begin{array}{c}\text { Cronbach's } \\
\text { Alpha if Item } \\
\text { Deleted }\end{array}$ & $\begin{array}{c}\text { Sy } \\
\text { ar } \\
\text { at }\end{array}$ & $\begin{array}{c}\text { Alpha } \\
>\end{array}$ & $\begin{array}{c}\text { Kete } \\
\text { rang } \\
\text { an }\end{array}$ \\
\hline \multirow{2}{*}{ Y1.1 } & & 0. & Terbu & Reali \\
& 0.610 & 6 & kti & bel \\
Y1.2 & 0.731 & 6 & $\begin{array}{c}\text { Terbu } \\
\text { kti }\end{array}$ & $\begin{array}{c}\text { Reali } \\
\text { bel }\end{array}$ \\
& & 0. & Terbu & Reali \\
Y1.3 & 0.717 & 6 & kti & bel \\
& & 0. & Terbu & Reali \\
Y1.4 & 0.678 & 6 & kti & bel \\
\hline
\end{tabular}

Sumber : Hasil pengolahan data pada Lampiran 4 
Dari hasil analisis data yang disebarkan maka terbukti bahwa seluruh item pertanyaan adalah Reliabel karena memiliki Alpha Cronbach lebih besar dari 0,6 .

\section{g. Uji Realibilitas Variabel Word of Mouth (WOM)}

Uji Reliabilitas dilakukan dengan tujuan untuk menguji sejauh mana alat pengukur dapat diandalkan atau dipercaya. Dalam Penelitian ini nilaiu reliabilitas suatu instrumen diterima jika memiliki Alpha Cronbach minimal 0,6.

Tabel 5.43

Hasil Uji Reabilitas Variabel Word of Mouth (WOM)

\begin{tabular}{|ccccc|}
\hline $\begin{array}{c}\text { Item } \\
\text { pertany } \\
\text { aan }\end{array}$ & $\begin{array}{c}\text { Cronbach's } \\
\text { Alpha if Item } \\
\text { Deleted }\end{array}$ & $\begin{array}{c}\text { Sy } \\
\text { ar } \\
\text { at }\end{array}$ & $\begin{array}{c}\text { Alpha } \\
\text { Syarat }\end{array}$ & $\begin{array}{c}\text { Kete } \\
\text { rang } \\
\text { an }\end{array}$ \\
\hline Y2.1 & 0.772 & $\begin{array}{c}0 . \\
6\end{array}$ & $\begin{array}{c}\text { Terbu } \\
\text { kti }\end{array}$ & $\begin{array}{c}\text { Reali } \\
\text { bel }\end{array}$ \\
Y2.1 & & 0. & Terbu & Reali \\
& 0.786 & 6 & kti & bel \\
Y2.3 & 0.821 & 6 & Terbu & Reali \\
& & kti & bel \\
\hline
\end{tabular}

Sumber : Hasil pengolahan data pada Lampiran 4

Dari hasil analisis data yang disebarkan maka terbukti bahwa seluruh item pertanyaan adalah Reliabel karena memiliki Alpha Cronbach lebih besar dari 0,6 .

\section{Analisa dan Interpretasi Data Bivariat dan Multivariat}

Analisis Data Analisis Jalur (Path Analisis)

1. Sub Struktural - 1 (Pengaruh Bukti Fisik,Kehandalan, Daya Tanggap, Jaminan, dan Kehandalan Terhadap Kepuasan Pasien)

Persamaan adalah

$\mathrm{Y}_{1}$ $\rho_{Y X 1} \mathrm{X}_{1}+\rho_{Y X 2} \mathrm{X}_{2}+\rho_{\mathrm{YX}} \mathrm{X}_{3}+\rho_{\mathrm{YX}} \mathrm{X}_{4}+\rho_{\mathrm{YX}} \mathrm{X}$ ${ }_{5}+\rho_{Y \varepsilon_{1}}$

a. Path Analisis

Dari hasil pengolahan data program SPSS pada sub strukrur 1 tersebut, terlihat dalam Lampiran 5. koefisien jalur yang di peroleh di uji sebagai berikut.
Tabel 5.44

\begin{tabular}{|c|c|c|c|c|c|c|c|}
\hline \multicolumn{8}{|c|}{ Rangkuman Koefisien Jalur Sub Struktur 1} \\
\hline $\begin{array}{c}\text { Pengaruh antar } \\
\text { Variabel }\end{array}$ & $\begin{array}{c}\text { Koefisien } \\
\text { jalur } \\
\text { (Beta) }\end{array}$ & Nilit & Sig & Nili F & Hasil pengujan & $\begin{array}{c}\text { Koefisian } \\
\text { determinan } R \\
\text { Squere atau } \\
R^{2} 2 \times x=\end{array}$ & $\begin{array}{l}\text { Koefisien } \\
\text { Variabel } \\
\text { lain (sisa) }\end{array}$ \\
\hline "Xi" terhadap Yi" & 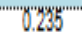 & "3.16\%" & 8.002 & \multirow{5}{*}{28.677} & Ho Dtolak/Signitikan & \multirow{5}{*}{0,328} & \multirow{5}{*}{$\begin{array}{c}0,672 \text { atau } \\
67.2 \%\end{array}$} \\
\hline "X2" terhadap Yi" & 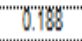 & $3.16 \%$ & 0.002 & & Ho Drolakisgnifikan & & \\
\hline "X3 terhadap Yi' & 0.182 & 2.866 & 0.004 & & Ho Ditolak/Sign fikan & & \\
\hline "X4 terhadap Yi" & "8.25\%" & $4.085 \%$ & 0.000 & & Ho Ditolak/Signifikan & & \\
\hline X5 terhadap Yi" & 0.247 & 3.958 & 0.000 & & Ho Ditolak/Signifikan & & \\
\hline
\end{tabular}

Berdasarkan tabel 5.44 diperoleh kerangka hubungan empiris antara X1, X2, $\mathrm{X} 3, \mathrm{X} 4, \mathrm{X} 5$ dan $\mathrm{Y} 1$ dapat dibuat dalam persamaan struktural sebagai berikut $\rho_{Y_{X 1} X_{1}+\rho_{Y X} X_{2}+\rho_{Y X} X_{3}+\rho_{Y X} X_{4}+\rho_{Y X} X_{5}+}$

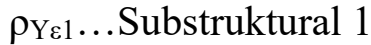

$$
\begin{aligned}
& 0,235 X_{1}+0,188 X_{2}+0,182 X_{3}+0,255 X_{4} \\
& +0,247 X_{5}+0,672 \varepsilon i \\
& \mathrm{R}^{2} \mathrm{Z} \cdot \mathrm{x} 1, \mathrm{x} 2 \quad=0,328 \\
& \rho_{Z} \varepsilon_{1}=1-R^{2} Z \times 1, \times 2=1-0,328=0,672
\end{aligned}
$$

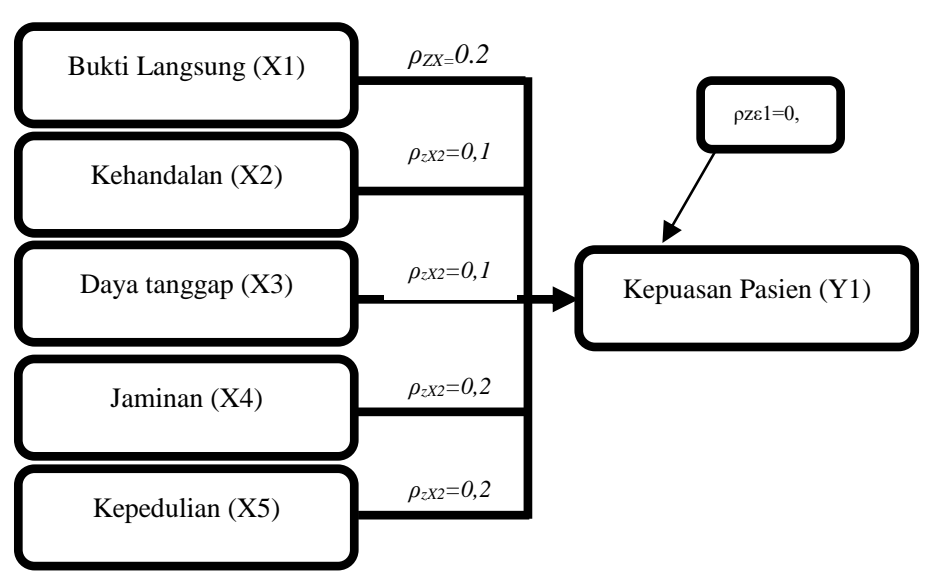

Gambar 5.2 Diagram Jalur Hubungan Kausal Empiris X1, X2, X3, X4, X5 dan Y1.

Sumber : Lampiran 5 diolah kembali.

b. Pengujian Hipotesis (Pengaruh Bukti Fisik,Kehandalan, Daya Tanggap, Jaminan, dan Kehandalan Terhadap Kepuasan Pasien)

1 Interkorelasi Antarvariabel

Uji ini digunakan dengan tujuan untuk membuktikan apakah variabel eksogen secara individual berpengaruh terhadap variabel endogen. Dalam menjawab hipotesis yang telah diajukan 
pada awal penelitian, menggunakan alat bantu analisis software SPSS .Berdasarkan hasil analisis pada tabel 5.44 dapat dinyatakan:

a. Pengaruh Bukti Fisik Terhadap Kepuasan Pasien (X1 dan Y1)

Berdasarkan tabel 5.44 diatas dapat dikertahui bahwa nilai probabilitas signifikansi (P) sebesar 0,002 lebih kecil daripada 5\% (syarat Signifikan) atau P $0.002<0.05$, Kesimpulan pembukti hipotesis Ho di tolak dan Ha di terima artinya hipotesis I yang berbunyi Bukti Fisik berpengaruh signifikan terhadap Kepuasan Pasien adalah benar atau teruji.

b. Pengaruh Kehandalan Terhadap Kepuasan Pasien (X2 dan Y1)

Berdasarkan tabel 5.44 diatas dapat dikertahui bahwa nilai probabilitas signifikansi (P) sebesar 0,002 lebih besar daripada 5\% (syarat Signifikan) atau P $0.002>0.05$, Kesimpulan pembukti hipotesis Ho di terima dan $\mathrm{HO}$ di tolak artinya hipótesis II yang berbunyi Kehandalan berpengaruh signifikan terhadap Kepuasan Pasien adalah salah atau tidak teruji.

c. Pengaruh Daya Tanggap Terhadap Kepuasan Pasien (X3 dan Y1)

Berdasarkan tabel 5.44 diatas dapat dikertahui bahwa nilai probabilitas signifikansi (P) sebesar 0,004 lebih kecil daripada 5\% (syarat Signifikan) atau P $0.004<0.05$, Kesimpulan pembukti hipotesis Ho di tolak dan Ha di terima artinya hipotesis I yang berbunyi Daya tanggap berpengaruh signifikan terhadap Kepuasan Pasiena dalah benar atau teruji.

d. Pengaruh Jaminan Terhadap Kepuasan Pasien (X4 dan Y1)

Berdasarkan tabel 5.44 diatas dapat dikertahui bahwa nilai probabilitas signifikansi (P) sebesar 0,000 lebih besar daripada 5\% (syarat Signifikan) atau P $0.000>0.05$, Kesimpulan pembukti hipotesis Ho di terima dan $\mathrm{H} 0$ di tolak artinya hipótesis
II yang berbunyi Jaminan berpengaruh signifikan terhadap Kepuasan Pasien adalah benar atau teruji.

e. Pengaruh Kepedulian Terhadap Kepuasan Pasien (X5 dan Y1)

Berdasarkan tabel 5.44 diatas dapat dikertahui bahwa nilai probabilitas signifikansi (P) sebesar 0,000 lebih kecil daripada 5\% (syarat Signifikan) atau P $0.000<0.05$, Kesimpulan pembukti hipotesis Ho di tolak dan Ha di terima artinya hipotesis I yang berbunyi Kepedulian berpengaruh signifikan terhadap Kepuasan Pasien adalah benar atau teruji.

2. Koefisien Jalur Pengaruh langsung dan tidak langsung substruktur 1

Koefisien Jalur, Pengaruh Langsung, Pengaruh Total dan uh Bersama Pengaruh Bukti Fisik (X1),Kehandalan(X2), Daya Tanggap(X3), (X4), Kepedulian (X5) Mempengaruhi secara Signifikant Terhadap Kepuasan Pasien (Y1)

\begin{tabular}{|c|c|c|c|c|}
\hline \multirow{3}{*}{ el } & \multirow{3}{*}{ Koefisien Jalur } & \multirow{2}{*}{\multicolumn{2}{|c|}{ Pengaruh }} & \\
\hline & & & & \multirow{2}{*}{$\begin{array}{c}\text { Pengaruh Bersama } \\
R^{2}{ }_{20}\end{array}$} \\
\hline & & Langsung & Total & \\
\hline ip Y1 & 0.235 & 0.235 & 0.235 & \\
\hline ip $Y_{2}$ & 0.188 & 0.188 & 0.188 & \\
\hline ip Y3 & 0.182 & 0.182 & 0.182 & \\
\hline $1 p \gamma_{4}$ & 0.255 & 0.255 & 0.255 & \\
\hline \multirow[t]{2}{*}{ ip Y5 } & 0.247 & 0.247 & 0.247 & \\
\hline & 0,672 & $1-0,328=0,672$ & & \\
\hline $\operatorname{dan} \times 5$ & & & & 0,328 \\
\hline
\end{tabular}

Berdasarkan hasil perhitungan analisi jalur struktur tersebut, maka dapat diketahui bahwa:

a. Besarnya kontribusi Bukti Fisik (X1) secara langsung mempengaruhi terhadap Kepuasan Pasien (Y1) adalah sebesar $0.235^{2}=0.055$ atau sebesar 5.5 $\%$

b. Besarnya kontribusi perilaku Kehandalan (X2) secara langsung mempengaruhi terhadap Kepuasan Pasien (Y1) adalah sebesar $0.188^{2}=$ 0.035 atau sebesar $3.5 \%$

c. Besarnya kontribusi Daya tanggap (X3) secara langsung mempengaruhi terhadap Kepuasan Pasien (Y1) adalah sebesar $0.182^{2}=0.033$ atau sebesar 3.3 $\%$

d. Besarnya kontribusi perilaku Jaminan (X4) secara langsung mempengaruhi terhadap Kepuasan Pasien (Y1) adalah 
sebesar $0.255^{2}=0.065$ atau sebesar $6.5 \%$

e. Besarnya kontribusi Kepedulian (X5) secara langsung mempengaruhi terhadap Kepuasan Pasien (Y1) adalah sebesar $0.247^{2}=0.061$ atau sebesar 6.1 $\%$

f. Besarnya kontribusi Bukti Fisik (X1), Kehandalan (X2) Daya tanggap (X3), Jaminan (X4), dan Kepedulian (X5) secara langsung mempengaruhi terhadap Kepuasan Pasien (Y1) adalah sebesar 0.328 atau sebesar $32.8 \%$.

2. Sub Struktural - 2 (Pengaruh Bukti Fisik, Kehandalan, Daya Tanggap, Jaminan, Kehandalan dan Kepuasan Pasien Terhadap Word of Mouth (WOM))

Persamaan adalah

$\mathrm{Y}_{2}$

$\rho_{\mathrm{YX} 1} \mathrm{X}_{1}+\rho_{\mathrm{YX} 2} \mathrm{X}_{2}+\rho_{\mathrm{YX}} \mathrm{X}_{3}+\rho_{\mathrm{YX}} \mathrm{X}_{4}+\rho_{\mathrm{YX}} \mathrm{X}_{5}+\rho_{\mathrm{Y} \varepsilon 1}$ $\varepsilon_{2}+\rho_{Y Y 1} \mathrm{Y}_{1}+\rho_{Y} \varepsilon_{2}$

a. Path Analisis

Dari hasil pengolahan data program SPSS pada sub strukrur 2 tersebut, terlihat dalam tabel 5.46 koefisien jalur yang di peroleh di uji sebagai berikut.

Tabel 5.46

\begin{tabular}{|c|c|c|c|c|c|c|}
\hline $\begin{array}{l}\text { Pengaruh antar } \\
\text { Variabel }\end{array}$ & $\begin{array}{c}\text { Koefisien } \\
\text { jalur } \\
\text { (Beta) }\end{array}$ & Nilait & $\mathrm{Sig}$ & Nilai F & Hasil pengujan & $\begin{array}{l}\text { Koefisien } \\
\text { determinan } \\
R \text { Squere } \\
\text { atau } R^{2} \times: 92\end{array}$ \\
\hline Xi terhadap Y2 & 0.133 & 2.183 & 0.030 & \multirow{6}{*}{42.741} & "Ho D Ditolaki Signifikan & \multirow{6}{*}{0,467} \\
\hline X2 terhadap Y2" & $-0.26 \%$ & -5.463 & 0.000 & & "Ho Drolak/Signifikan & \\
\hline "X3" terhadap YY2" & 8.535 & 10.252 & 0.000 & & Ho Drolak/Signifikan & \\
\hline X4 terhadap Y2 & 0.285 & 5.479 & 0.000 & & "Ho Ditolak/Signifikan & \\
\hline "X5" terhadap YY2" & 8.343 & 4.214 & 0.000 & & "Ho Drolak/Signifikan & \\
\hline 'Yi Terhadap Y2' & -0.163 & -3.455 & 0.001 & & Ho Ditolak Sipnifikan & \\
\hline
\end{tabular}

Berdasarkan tabel 5.46 diperoleh kerangka hubungan empiris antara $\mathrm{X} 1, \mathrm{X} 2, \mathrm{X} 3, \mathrm{X} 4, \mathrm{X} 5, \mathrm{Y} 1$ dan $\mathrm{Y} 2$ dapat dibuat dalam persamaan struktural sebagai berikut

$\mathrm{Y}_{2}$

$\rho_{Y_{X} 1} X_{1}+\rho_{Y X} X_{2}+\rho_{Y X} X_{3}+\rho_{Y X} X_{4}+\rho_{Y X} X_{5}+\rho_{Y_{\varepsilon} 1 \varepsilon 2}+\rho_{Y}$

${ }_{Y 1} \mathrm{Y}_{1}+\rho_{Y \varepsilon_{2}}$ Substruktural 2

$=0,133 \mathrm{X}_{1}-0,267 \mathrm{X}_{2}+0.535 \mathrm{X}_{3}+0,285 \mathrm{X}_{4}$

$+0,373 X_{5}-0.163+0,533 \varepsilon_{2}$

$\mathrm{R}^{2} \mathrm{Y} . \mathrm{x} 1, \mathrm{x} 2=0,467$

$\rho_{Y \varepsilon_{1}} \varepsilon_{1}=1-\mathrm{R}_{\mathrm{y} . \mathrm{x} 1, \mathrm{x} 2, \mathrm{z}}=1-0,467=0,533$

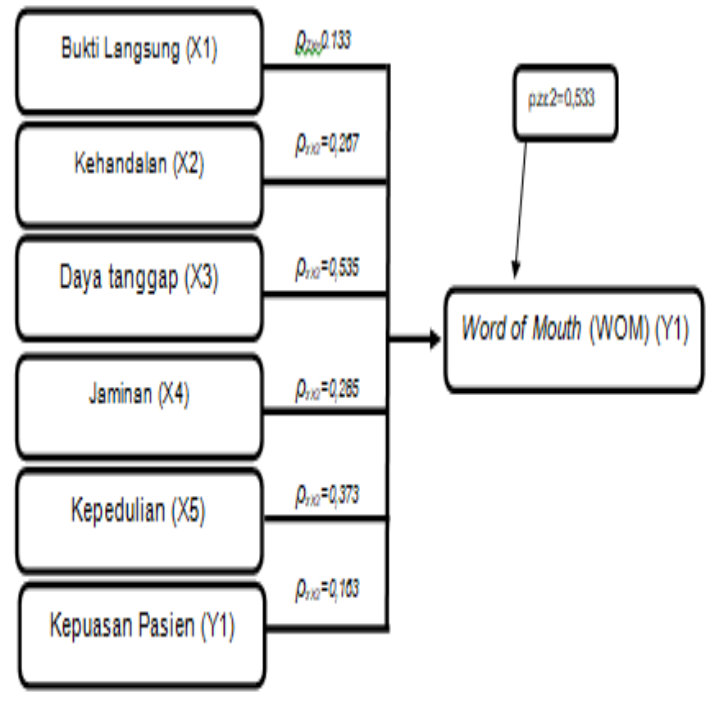

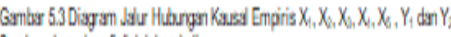

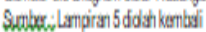

b. Pengujian Hipotesis (substruktural 2 Pengaruh Bukti Fisik,Kehandalan, Daya Tanggap, Jaminan, Kehandalan, dan Kepuasan Pasien Terhadap Word of Mouth (WOM))

\section{Interkorelasi Antarvariabel}

Uji ini digunakan dengan tujuan untuk membuktikan apakah variabel eksogen secara sendiri sendiri berpengaruh terhadap variabel endogen. Dalam menjawab hipotesis yang telah diajukan pada awal penelitian, menggunakan alat bantu analisis software SPSS. Berdasarkan hasil analisis pada tabel 5.46 dapat dinyatakan:

a. Pengaruh Bukti Fisik Terhadap Word of Mouth (WOM) (X1 dan Y2)

Berdasarkan tabel 5.46 diatas dapat dikertahui bahwa nilai probabilitas signifikansi (P) sebesar 0.030 lebih kecil daripada 5\% (syarat Signifikan) atau P $0.030>0.05$, Kesimpulan pembukti hipotesis Ho di tolak dan Ha diterima artinya hipotesis III yang berbunyi Bukti Fisik berpengaruh signifikan terhadap Bukti Fisik adalah benar atau teruji.

b. Pengaruh Kehandalan Terhadap Word of Mouth (WOM) (X2 dan Y)

Berdasarkan tabel 5.46 diatas dapat $\mathrm{d} \rho \mathrm{gz} 2=0,533$ nahwa nilai probabilita (P) sebesar 
0,000 lebih kecil daripada 5\% (syarat Signifikan) atau P $0,000<0.05$ Kesimpulan pembukti hipotesis Ho di tolak dan Ha di terima artinya hipótesis IV yang berbunyi Kehandalan berpengaruh signifikan terhadap Bukti Fisik adalah benar atau teruji.

c. Pengaruh Daya Tanggap Terhadap Word of Mouth (WOM) (X3 dan Y2) Berdasarkan tabel 5.46 diatas dapat dikertahui bahwa nilai probabilitas signifikansi (P) sebesar 0.000 lebih kecil daripada 5\% (syarat Signifikan) atau P $0.000>0.05$, Kesimpulan pembukti hipotesis Ho di tolak dan Ha diterima artinya hipotesis III yang berbunyi Daya Tanggap berpengaruh signifikan terhadap Bukti Fisik adalah benar atau teruji.

d. Pengaruh Jaminan Terhadap Word of Mouth (WOM) (X4 dan Y2)

Berdasarkan tabel 5.46 diatas dapat dikertahui bahwa nilai probabilitas signifikansi (P) sebesar 0,000 lebih kecil daripada 5\% (syarat Signifikan) atau P $0,000<0.05$ Kesimpulan pembukti hipotesis Ho di tolak dan Ha di terima artinya hipótesis IV yang berbunyi Jaminan berpengaruh signifikan terhadap Bukti Fisik adalah benar atau teruji.

e. Pengaruh Kepedulian Terhadap Word of Mouth (WOM) (X5 dan Y2)

Berdasarkan tabel 5.46 diatas dapat dikertahui bahwa nilai probabilitas signifikansi (P) sebesar 0,000 lebih kecil daripada 5\% (syarat Signifikan) atau P $0,000<0.05$ Kesimpulan pembukti hipotesis Ho di tolak dan Ha di terima artinya hipótesis IV yang berbunyi Kepedulian berpengaruh signifikan terhadap Bukti Fisik adalah benar atau teruji.

f. Pengaruh Kepuasan Pasien Terhadap Word of Mouth (WOM) (Y1 dan Y2)

Berdasarkan tabel 5.46 diatas dapat dikertahui bahwa nilai probabilitas signifikansi (P) sebesar 0.001 lebih kecil daripada 5\% (syarat Signifikan) atau P $0.001<0.05$, Kesimpulan pembukti hipotesis Ho di tolak dan Ha di terima artinya hipotesis
V yang berbunyi Kepuasan Pasienberpengaruh signifikan terhadap Bukti Fisik adalah benar atau teruji.

\section{Pengaruh langsung dan tidak langsung substruktur 2}

Tabel 5.47

Koefisien Jalur, Pengaruh Langsung. Pengaruh Total dan Pengaruh Bersama Pengaruh Bukti Fisik $(X 1)$, Kehandalan $(X 2)$, Days Tanggap $(X 3)$, Jaminan $(X 4)$, Kepedulian (X5), dan Kepussan Pasien (Y1) Mempengaruhi secara Signifikant terhadap Word of Mouth (WOM) (Y2)

\begin{tabular}{|c|c|c|c|c|}
\hline \multirow{2}{*}{ Variabel } & \multirow{2}{*}{$\begin{array}{l}\text { Koefisien } \\
\text { Jalur }\end{array}$} & \multicolumn{2}{|c|}{ Pengaruh } & \multirow{2}{*}{$\begin{array}{c}\text { Pengaruh Bersama } \\
R_{r a}^{2}\end{array}$} \\
\hline & & Langsung & Total & \\
\hline$X_{1}$ terhadap $Y_{2}$ & 0.133 & 0.133 & 0.133 & \\
\hline$X_{2}$ terhadap $Y_{2}$ & -0.267 & -0.267 & -0.267 & \\
\hline$X_{3}$ terhadap Y2 & 0.535 & 0.535 & 0.535 & \\
\hline$X_{4}$ terhadap $Y_{2}$ & 0.285 & 0.285 & 0.285 & \\
\hline$X 5$ terhadap Y2 & 0.373 & 0.373 & 0.373 & \\
\hline$Y_{1}$ terhadap Y2 & 0.163 & 0.163 & -0.163 & \\
\hline $\mathrm{ei}$ & 0,533 & $10,467=0,533$ & & \\
\hline$x_{1}, x_{2}, 2$ & & & & 0.467 \\
\hline
\end{tabular}

Berdasark an hasil perhitungan analisi jalur struktur pada tabel 5.47, maka dapat diketahui bahwa:

a. Besarnya kontribusi Bukti Fisik (X1) secara langsung mempengaruhi terhadap Word of Mouth (WOM) (Y2) adalah sebesar $0,133^{2}=0.018$ atau sebesar $1.8 \%$.

b. Besarnya kontribusi perilaku Kehandalan (X2) secara langsung mempengaruhi terhadap Word of Mouth (WOM) (Y2) adalah sebesar $0,267^{2}=0.071$ atau sebesar $7.1 \%$.

c. Besarnya kontribusi Bukti Fisik (X3) secara langsung mempengaruhi terhadap Word of Mouth (WOM) (Y2) adalah sebesar $0,535^{2}=0.286$ atau sebesar 28.6\%.

d. Besarnya kontribusi perilaku Kehandalan (X4) secara langsung mempengaruhi terhadap Word of Mouth (WOM) (Y) adalah sebesar $0,285^{2}=0.081$ atau sebesar $8.1 \%$.

e. Besarnya kontribusi Bukti Fisik (X5) secara langsung mempengaruhi terhadap Word of Mouth (WOM) (Y2) adalah sebesar $0,373^{2}=0.139$ atau sebesar $13.9 \%$.

f. Besarnya kontribusi Kepuasan Pasien (Y1) secara langsung mempengaruhi Word of Mouth (WOM) (Y2) adalah sebesar $0,163=0.027$ atau sebesar $2.7 \%$. 
g. Besarnya kontribusi Bukti Fisik (X1),Kehandalan(X2), Daya Tanggap (X3), Jaminan (X4), Kehandalan (X5), dan Kepuasan Pasien (Y1) secara langsung mempengaruhi terhadap Word of Mouth (WOM) (Y2) adalah sebesar 0,467 atau sebesar $46.7 \%$.

\section{Uji Hipotesa}

Berdasarkan hasil perhitungan secara keseluruhan, maka dapat disimpulkan hipotesa secara objective sebagai berikut:

1. Persamaan substruktural $\mathbf{1}$ berbunyi Bukti Fisik (X1), Kehandalan (X2) Daya tanggap (X3), Jaminan (X4), dan Kepedulian (X5) memiliki pengaruh secara bersama sama terhadap Kepuasan Pasien (Y1) dengan dinyatakan signifikan. Secara individu semua sub variabel diterima baik itu antara Bukti Fisik (X1) berpengaruh terhadap Kepuasan Pasien (Y1) adalah significant dan begitu juga dengan pengaruh Kehandalan (X2) dengan Kepuasan Pasien (Y1), Daya tanggap (X3) berpengaruh terhadap Kepuasan Pasien (Y1), Jaminan (X4) berpengaruh terhadap Kepuasan Pasien (Y1), dan Kepedulian (X5) berpengaruh terhadap Kepuasan Pasien (Y1) di Puskesmas Kelua Kabupaten Tabalong menunjukkan signifikant. Hal ini membuktikan hipotesa pertama yang menyatakan terdapat pengaruh antara Bukti Fisik (X1),Kehandalan(X2), Daya Tanggap (X3), Jaminan (X4), Kehandalan (X5) Terhadap Kepuasan Pasien secara parsial

2. Persamaan substruktural 2 berbunyi Bukti Fisik (X1),Kehandalan(X2), Daya Tanggap (X3), Jaminan (X4), Kehandalan (X5) dan Kepuasan Pasien (Y1) memiliki pengaruh secara bersama sama terhadap Word of Mouth (WOM) (Y2) dengan dinyatakan signifikan. Secara individu semua sub variabel diterima baik itu antara Bukti Fisik (X1) terhadap Word of Mouth (WOM) (Y2) adalah significant, Kehandalan (X2) dengan Word of Mouth (WOM) (Y2) signifikant. Daya Tanggap (X3) terhadap Word of Mouth (WOM) (Y2) adalah significant, Jaminan (X4) terhadap Word of Mouth (WOM) (Y2) adalah significant, Kehandalan (X5) terhadap Word of Mouth (WOM) (Y2) adalah significant dan Keupasan Pasien (Y1) terhadap Word of Mouth (WOM) (Y2) adalah significant $\mathrm{Hal}$ ini membuktikan hipotesa kedua yang menyatakan terdapat pengaruh antara variabel Bukti FisikKehandalan, Daya Tanggap, Jaminan, Kehandalan dan Kepuasan Pasien berpengaruh terhadap Word of Mouth (WOM) secara parsial dan simultan

3. Besarnya Pengaruh langsung dan Tidak Langsung

Untuk melihat Tingkat signifikansi dan Beberapa besar pengaruh langsung dan tidak langsung (melalui Y) dan pengaruh total tentang Bukti Fisik (X1),Kehandalan(X2), Daya Tanggap (X3), Jaminan (X4), Kehandalan (X5) dan Kepuasan Pasien (Y1) Word of Mouth (WOM) (Y2) di Puskesmas Kelua Kabupaten Tabalong. Mengukur nilai pengaruh lemah atau kuat analisis path dalam penelitian ini, Sumarno berpendapat dalam Murdijanto (1994) : Apabila nilai koefisien antara 0 sampai 0,164 maka nilai path analisis tidak ada pengaruhnya, nilai koefisien 0,165 sampai 0,335 maka nilai path analisisnya lemah dan apabila nilai koefisien di atas 0,335 maka pengaruh nilai path analisisnya kuat.

Tabel 5.48

Nilai Path Analysis

\begin{tabular}{|c|l|c|}
\hline No & \multicolumn{1}{|c|}{ Nilai } & Pengaruh \\
\hline 1 & 0 & Sampai 0,114 \\
2 & 0,115 Sampai 0,335 & Sangat Lemah \\
3 & 0,335 Ke atas & Lemah \\
\hline
\end{tabular}

Sumber: Murdijanto

Berdasarkan hasil perhitungan path analisis dengan menggunakan program SPSS versi 21 dapat disimpulkan hipotesa sebagai berikut: 
Tabel 5.49

Rangkuman Dekomposisi Dari Koefisien Jalur, Pengaruh Langsung dan Tidak Langsung dan Pengaruh Total Tentang Bukfi Fisik $\left(X_{1}\right)$ Kehandalan $\left(X_{2}\right)$, Kepuasan Pasien (Y1) terhadap Word of Mouth (WOM) (Y) Puskesmas

\begin{tabular}{|c|c|c|c|c|}
\hline \multirow{3}{*}{$\begin{array}{l}\text { Pengaruh } \\
\text { Variabel }\end{array}$} & \multicolumn{3}{|c|}{ Pengaruh Kausal } & \multirow{3}{*}{ Total } \\
\hline & \multirow{2}{*}{ Langsung } & \multirow{2}{*}{ Sig } & Tidak Langsung & \\
\hline & & & Melalui Y & \\
\hline $\mathrm{X}_{1}$ Terhadap $Y_{1}$ & 0.235 & 0.002 & & \\
\hline$X_{1}$ terhadap $Y_{2}$ & 0.133 & 0.030 & $(0.235) \times(0.133)=0.031$ & 0.031 \\
\hline $\mathrm{X}_{2}$ Terhadap $Y_{1}$ & 0.188 & 0.002 & & \\
\hline $\mathrm{X}_{2}$ Terhadap $\mathrm{Y}_{2}$ & 0.267 & 0.000 & $(0.188) \times(0.267)=0.074$ & 0.074 \\
\hline $\mathrm{X}_{\mathrm{A}}$ Terhadap $\mathrm{Y}_{1}$ & 0.182 & 0.004 & & \\
\hline$X_{1}$ Terhadap $Y_{2}$ & 0.535 & 0.000 & $(0.182) \times(0.535)=0.097$ & 0.097 \\
\hline$X_{4}$ Terhadap $Y_{1}$ & 0.255 & 0.000 & & \\
\hline$X_{4}$ Terhadap $Y_{2}$ & 0.285 & 0.000 & $(0.255) \times(0.285)=0.073$ & 0.073 \\
\hline $\mathrm{X}_{4}$ Terhadap $Y_{1}$ & 0.247 & 0.000 & & \\
\hline$X_{1}$ Terhadap $Y_{2}$ & 0.373 & 0.000 & $(0.247) \times(0.373)=0.092$ & 0.092 \\
\hline$Y_{1}$ Terhadap $Y_{2}$ & 0.163 & 0.001 & & 0.163 \\
\hline
\end{tabular}

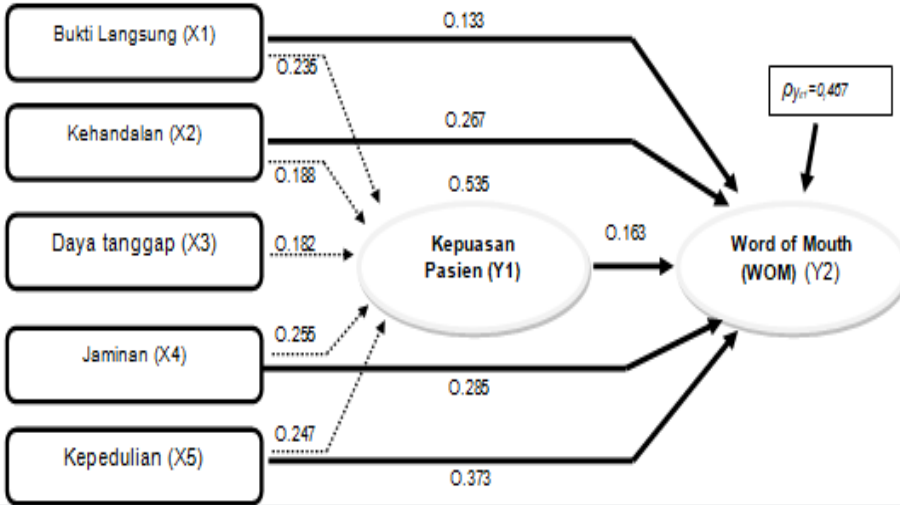

a. Bukti Fisik berpengaruh secara significant terhadap Kepuasan Pasien hal ini ditandai dengan nilai Sig. 0.002 lebih kecil dari probabilitas 0.05 artitinya adalah signifikant. Besar pengaruh langsung variabel $\mathrm{X} 1$ terhadap $\mathrm{Y} 1=0.235$ artinya Bukti Fisik memiliki pengaruh secara keseluruhan terhadap Kepuasan Pasien (Y1) dilingkungan Pasien Puskesmas Kelua Kabupaten Tabalong sebesar 23.5\% yang munjukkan pengaruh yang lemah

b. Bukti Fisik berpengaruh secara significant terhadap Word of Mouth (WOM) hal ini ditandai dengan nilai Sig. 0.030 lebih kecil dari probabilitas 0.05 artinya adalah signifikant Besar Pengaruh Bukti Fisik terhadap Word of Mouth (WOM) adalah Pengaruh langsung terhadap variabel $\mathrm{Y}=0.133$ pengaruh tidak langsung $\mathrm{X} 1$ dan $\mathrm{Y} 2$ melalui Y1 adalah sebesar 0.031 artinya Bukti Fisik (X1) memiliki pengaruh secara keseluruhan terhadap Word of Mouth (WOM) (Y2) Pasien Puskesmas Kelua Kabupaten Tabalong sebesar $3.1 \%$ dan menunjukkan pengaruh yang sangat lemah c. Kehandalan berpengaruh secara significant terhadap Kepuasan Pasien hal ini ditandai dengan nilai Sig. 0.002 lebih kecil dari probabilitas 0.05 artitinya adalah signifikant. Besar Pengaruh langsung variabel X2 terhadap $\mathrm{Y} 1=0.188$ artinya Kehandalan (X2) memiliki pengaruh secara keseluruhan terhadap Kepuasan Pasien (Y1) Pasien Puskesmas Kelua Kabupaten Tabalong sebesar 18.8\% dan menunjukkan pengaruh yang lemah

d. Kehandalan berpengaruh secara significant terhadap Word of Mouth (WOM) hal ini ditandai dengan nilai Sig. 0.000 lebih kecil dari probabilitas 0.05 artinya adalah signifikant. Besar Pengaruh langsung variabel X2 terhadap $\mathrm{Y} 2=0.267$, pengaruh tidak langsung X2 dan Y2 melalui Y1 adalah sebesar 0.188 artinya Kehandalan (X2) memiliki pengaruh secara keseluruhan terhadap Word of Mouth (WOM) (Y) sebesar $5.0 \%$ dan menunjukkan pengaruh yang sangat lemah

e. Daya tanggap (X3) berpengaruh secara significant terhadap Kepuasan Pasien hal ini ditandai dengan nilai Sig. 0.004 lebih kecil dari probabilitas 0.05 artitinya adalah signifikant. Besar pengaruh langsung variabel $\mathrm{X} 3$ terhadap $\mathrm{Y} 1=0.182$ artinya Daya tanggap (X3) memiliki pengaruh secara keseluruhan terhadap Kepuasan Pasien (Y1) dilingkungan Pasien Puskesmas Kelua Kabupaten Tabalong sebesar $18,2 \%$ yang munjukkan pengaruh yang lemah

f. Daya tanggap berpengaruh secara significant terhadap Word of Mouth (WOM) hal ini ditandai dengan nilai Sig. 0.000 lebih kecil dari probabilitas 0.05 artinya adalah signifikant Besar Pengaruh Daya tanggap (X3) terhadap Word of Mouth (WOM) adalah Pengaruh langsung terhadap variabel $\mathrm{Y}$ $=0.535$ pengaruh tidak langsung $\mathrm{X} 3$ dan Y2 melalui Y1 adalah sebesar 0.097 artinya Daya tanggap (X3) memiliki pengaruh secara keseluruhan terhadap Word of Mouth (WOM) (Y2) Pasien Puskesmas Kelua Kabupaten Tabalong 
sebesar $9.7 \%$ dan menunjukkan pengaruh yang sangat lemah

g. Jaminan berpengaruh secara significant terhadap Kepuasan Pasien hal ini ditandai dengan nilai Sig. 0.000 lebih kecil dari probabilitas 0.05 artitinya adalah signifikant. Besar Pengaruh langsung variabel $\mathrm{X} 4$ terhadap $\mathrm{Y} 1=$ 0.255 artinya Jaminan (X4) memiliki pengaruh secara keseluruhan terhadap Kepuasan Pasien (Y1) Pasien Puskesmas Kelua Kabupaten Tabalong sebesar 25.5\% dan menunjukkan pengaruh yang lemah

h. Jaminan berpengaruh secara significant terhadap Word of Mouth (WOM) hal ini ditandai dengan nilai Sig. 0.000 lebih kecil dari probabilitas 0.05 artinya adalah signifikant. Besar Pengaruh langsung variabel X4 terhadap $\mathrm{Y} 2=$ 0.285 , pengaruh tidak langsung $\mathrm{X} 4$ dan Y2 melalui Y1 adalah sebesar 0.073 artinya Jaminan (X4) memiliki pengaruh secara keseluruhan terhadap Word of Mouth (WOM) (Y) sebesar $7.3 \%$ dan menunjukkan pengaruh yang sangat lemah

i. Kepedulian berpengaruh secara significant terhadap Kepuasan Pasien hal ini ditandai dengan nilai Sig. 0.002 lebih kecil dari probabilitas 0.05 artitinya adalah signifikant. Besar Pengaruh langsung variabel X5 terhadap Y1 $=0.247$ artinya Kepedulian (X5) memiliki pengaruh secara keseluruhan terhadap Kepuasan Pasien (Y1) Pasien Puskesmas Kelua Kabupaten Tabalong sebesar $18.8 \%$ dan menunjukkan pengaruh yang lemah

j. Kepedulian berpengaruh secara significant terhadap Word of Mouth (WOM) hal ini ditandai dengan nilai Sig. 0.000 lebih kecil dari probabilitas 0.05 artinya adalah signifikant. Besar Pengaruh langsung variabel X5 terhadap $\mathrm{Y} 2=0.373$, pengaruh tidak langsung X5 dan Y2 melalui Y1 adalah sebesar 0.092 artinya Kepedulian (X5) memiliki pengaruh secara keseluruhan terhadap Word of Mouth (WOM) (Y) sebesar $9.2 \%$ dan menunjukkan pengaruh yang sangat lemah k. Kepuasan Pasien berpengaruh secara significant terhadap Word of Mouth (WOM) hal ini ditandai dengan nilai Sig. 0.001 lebih kecil dari probabilitas 0.05 artitinya adalah signifikant. Besar Pengaruh langsung Variabel Y1 terhadap Y2 $=0.163$ artinya Kepuasan Pasien (Y1) memiliki pengaruh secara keseluruhan terhadap Word of Mouth (WOM) (Y2) Pasien Puskesmas Kelua Kabupaten Tabalong sebesar 0.163 atau sebesar $16.3 \%$ dan menunjukkan pengaruh yang Lemah, pengaruh ini dinilai lemah karena kebanyakan masyarakat puskesmas Keluasedikit agak tertutup dengan penyampaian suatu hal yang baik. Hal ini disebabkan karena mayoritas masyarakat disana bekerja jadi tidak sempat untuk membicarakan hal hal di luar pekerjaannya.

\section{Pembahasan}

Berdasarkan hasil perhitungan secara keseluruhan, maka dapat disimpulkan hipotesa secara objektif sebagai berikut:

1. Pengaruh Bukti Fisik Terhadap Kepuasan Pasien

Bukti Fisik berpengaruh positif Terhadap Kepuasan Pasien dimana Bukti Fisik Dapat meliputi fasilitas fisik (gedung, buku, meja dan kursi, dan sebagainya), teknologi (peralatan dan perlengkapan yang dipergunakan), serta penampilan Petugas Kesehatan, dengan nilai Sig. 0.002 lebih kecil dari probabilitas 0.05 artitinya adalah signifikant. Besar pengaruh langsung variabel X1 terhadap Y1 $=0.235$ artinya Bukti Fisik memiliki pengaruh secara keseluruhan terhadap Kepuasan Pasien (Y1) sebesar $23.5 \%$ yang munjukkan pengaruh yang lemah

2. Pengaruh Kehandalan Terhadap Kepuasan Pasien

Kehandalan berpengaruh positif Terhadap Kepuasan Pasien dimana terbukti bahwa Kemampuan Puskesmas memberikan pelayanan sesuai dengan apa yang dijanjikan secara akurat dan terpercaya, dengan nilai Sig. 0.002 lebih kecil dari probabilitas 0.05 artitinya 
adalah signifikant. Besar Pengaruh langsung variabel $\mathrm{X} 2$ terhadap $\mathrm{Y} 1=$ 0.188 artinya Kehandalan memiliki pengaruh secara keseluruhan terhadap Kepuasan Pasien (Y1) Pasien sebesar $18.8 \%$ dan menunjukkan pengaruh yang lemah

3. Pengaruh Daya Tanggap Terhadap Kepuasan Pasien

Daya tanggap berpengaruh positif Terhadap Kepuasan Pasien dimana Daya tanggap Dapat meliputi Respon atau kesigapan serta kemampuan untuk membantu pelanggan dan meningkatkan kecepatan pelayanannya, dengan nilai Sig. 0.004 lebih kecil dari probabilitas 0.05 artitinya adalah signifikant. Besar pengaruh langsung variabel $\mathrm{X} 3$ terhadap $\mathrm{Y} 1=0.182$ artinya Daya tanggap (X3) memiliki pengaruh secara keseluruhan terhadap Kepuasan Pasien (Y1) dilingkungan Pasien Puskesmas Kelua Kabupaten Tabalong sebesar 18,2\% yang munjukkan pengaruh yang lemah

4. Pengaruh Jaminan Terhadap Kepuasan Pasien

Jaminan berpengaruh positif Terhadap Kepuasan Pasien dimana Bukti Fisik Dapat meliputi Kemampuan karyawan atas pengetahuan terhadap produk secara tepat, jaminan keselamatan, keterampilan dalam memberikan keamanan, dalam memanfaatkan jasa yang ditawarkan dan kemampuan dalam menanamkan kepercayaan pelanggan terhadap perusahaan, dengan nilai Sig. 0.000 lebih kecil dari probabilitas 0.05 artitinya adalah signifikant. Besar Pengaruh langsung variabel $\mathrm{X} 4$ terhadap $\mathrm{Y} 1=0.255$ artinya Jaminan (X4) memiliki pengaruh secara keseluruhan terhadap Kepuasan Pasien (Y1) Pasien Puskesmas Kelua Kabupaten Tabalong sebesar 25.5\% dan menunjukkan pengaruh yang lemah

5. Pengaruh Kepedulian Terhadap Kepuasan Pasien

Kepedulian berpengaruh positif Terhadap Kepuasan Pasien dimana Kepedulian Dapat meliputi Memberikan perhatian secara individual penuh kepada pasien dan keluarganya, seperti kemudahan untuk menghubungi, kemampuan untuk berkomunikasi, perhatian yang tinggi kepada pasien, dengan nilai Sig. 0.002 lebih kecil dari probabilitas 0.05 artitinya adalah signifikant. Besar Pengaruh langsung variabel X5 terhadap Y1 $=0.247$ artinya Kepedulian (X5) memiliki pengaruh secara keseluruhan terhadap Kepuasan Pasien (Y1) Pasien Puskesmas Kelua Kabupaten Tabalong sebesar 18.8\% dan menunjukkan pengaruh yang lemah

6. Pengaruh Bukti Fisik Terhadap Word of Mouth (WOM)

Bukti Fisik berpengaruh positif Terhadap Word of Mouth (WOM) dimana WOM yang baik merupakan gambaran kualitatif tentang bukti fisik yang baik dari puskesmas tersebut, dengan nilai Sig. 0.030 lebih kecil dari probabilitas 0.05 artinya adalah signifikant Besar Pengaruh Bukti Fisik terhadap Word of Mouth (WOM) adalah Pengaruh langsung terhadap variabel $\mathrm{Y}=0.133$ pengaruh tidak langsung X1 dan Y2 melalui Y1 adalah sebesar 0.031 artinya Bukti Fisik (X1) memiliki pengaruh secara keseluruhan terhadap Word of Mouth (WOM) (Y2) Pasien sebesar $3.1 \%$ dan menunjukkan pengaruh yang sangat lemah

7. Pengaruh Kehandalan Terhadap Word of Mouth (WOM)

Kehandalan berpengaruh positif Terhadap Word of Mouth (WOM) dimana WOM yang baik merupakan gambaran kualitatif tentang bukti fisik yang baik dari puskesmas tersebut, dengan nilai Sig. 0.000 lebih kecil dari probabilitas 0.05 artinya adalah signifikant. Besar Pengaruh langsung variabel $\mathrm{X} 2$ terhadap $\mathrm{Y} 2=0.267$, pengaruh tidak langsung $\mathrm{X} 2$ dan $\mathrm{Y} 2$ melalui Y1 adalah sebesar 0.188 artinya Kehandalan (X2) memiliki pengaruh secara keseluruhan terhadap Word of Mouth (WOM) (Y) sebesar 5.0\% dan menunjukkan pengaruh yang sangat lemah

8. Pengaruh Daya Tanggap Terhadap Word of Mouth (WOM) 
Daya tanggap berpengaruh positif Terhadap Word of Mouth (WOM) dimana WOM yang baik merupakan gambaran kualitatif tentang Daya tanggap yang baik dari puskesmas tersebut.

9. Pengaruh Jaminan Terhadap Word of Mouth (WOM)

Jaminan berpengaruh positif Terhadap Word of Mouth (WOM) dimana WOM yang baik merupakan gambaran kualitatif tentang Jaminan yang baik dari puskesmas tersebut. dengan nilai Sig. 0.000 lebih kecil dari probabilitas 0.05 artinya adalah signifikant. Besar Pengaruh langsung variabel $\mathrm{X} 4$ terhadap $\mathrm{Y} 2=0.285$, pengaruh tidak langsung X4 dan Y2 melalui Y1 adalah sebesar 0.073 artinya Jaminan (X4) memiliki pengaruh secara keseluruhan terhadap Word of Mouth (WOM) (Y) sebesar $7.3 \%$ dan menunjukkan pengaruh yang sangat lemah

10. Pengaruh Kepedulian Terhadap Word of Mouth (WOM)

Kepedulian berpengaruh positif Terhadap Word of Mouth (WOM) dimana WOM yang baik merupakan gambaran kualitatif tentang Kepedulian yang baik dari puskesmas tersebut, dengan nilai Sig. 0.000 lebih kecil dari probabilitas 0.05 artinya adalah signifikant. Besar Pengaruh langsung variabel X5 terhadap $\mathrm{Y} 2=0.373$, pengaruh tidak langsung X5 dan Y2 melalui Y1 adalah sebesar 0.092 artinya Kepedulian (X5) memiliki pengaruh secara keseluruhan terhadap Word of Mouth (WOM) (Y) sebesar 9.2\% dan menunjukkan pengaruh yang sangat lemah

11. Pengaruh Kepuasan Pasien Terhadap Word of Mouth (WOM)

Bukti Fisik berpengaruh positif Terhadap Word of Mouth (WOM) dimana WOM yang baik merupakan gambaran kualitatif tentang bukti fisik yang baik dari puskesmas tersebut. dengan nilai Sig. 0.001 lebih kecil dari probabilitas 0.05 artitinya adalah signifikant. Besar Pengaruh langsung Variabel Y1 terhadap Y2 $=0.163$ artinya Kepuasan Pasien (Y1) memiliki pengaruh secara keseluruhan terhadap Word of Mouth (WOM) (Y2) Pasien Puskesmas Kelua Kabupaten Tabalong sebesar 0.163 atau sebesar $16.3 \%$ dan menunjukkan pengaruh yang Lemah

\section{Imlikasi Hasil Penelitian}

Berdasarkan hasil perhitungan secara keseluruhan, maka dapat Implikasi Hasil Penelitian adalah sebagai berikut:

1. Implikasi Faktor Pengaruh Bukti Fisik Terhadap Kepuasan Pasien

Telah teruji bahwa Bukti Fisik berpengaruh positif Terhadap Kepuasan Pasien dimana Bukti Fisik Dapat meliputi fasilitas fisik (gedung, buku, meja dan kursi, dan sebagainya), teknologi (peralatan dan perlengkapan yang dipergunakan), serta penampilan Petugas Kesehatan. Berdasarkan pada hasil penelitian yang menunjukkan adanya pengaruh yang positif dan signifikan antara Bukti Fisik terhadap Kepuasan Pasien di Puskesmas Kelua Kabupaten Tabalong, maka diharapkan Puskesmas tersebut dapat lebih meningkatkan Bukti Fisik yang baik dalam kapasitas sebagai pelayanan masyarakat. Temuan penelitian ini sejalan dengan penelitian yang dilakukan Retno Dwi 2010, dengan judul Analisis pengaruh tingkat kualitas pelayanan jasa Puskesmas terhadap kepuasan pasien di Puskesmas Gunungpati Semarang. yang menemukan hasil menunjukkan bahwa Terdapat pengaruh langsung Kualitas Pelayanan terhadap Kepuasan Pasien akuntansi dan ada pengaruh tidak langsung antara Kualitas pelayanan terhadap Puskesmas Gunungpati Semarang. Adapun persamaan penelitian terdahulu ini dengan penelitian saat ini adalah sama - sama menggunakan variabel Kualitas Pelayanan terhadap Kepuasan Pasien, menggunakan path analisis sedangkan perbedanaannya adalah penelitian saat ini mengembangkan variabel populasi dan sampel, Lokasi penelitian, waktu 
penelitian dan Menggunakan Regresi Berganda.

2. Pengaruh Kehandalan Terhadap Kepuasan Pasien

Telah teruji bahwa Kehandalan berpengaruh positif Terhadap Kepuasan Pasien dimana terbukti bahwa Kemampuan Puskesmas memberikan pelayanan sesuai dengan apa yang dijanjikan secara akurat dan terpercaya. Puskesmas harus mampu memberikan pelayanan handal dalam melayani masyarakat. Petugas puskesmas yang handal dan baik akan meningkatkan kepuasan pasien yang akan berobat di sana. Temuan penelitian ini sejalan dengan penelitian yang dilakukan Retno Dwi 2010, dengan judul Analisis pengaruh tingkat kualitas pelayanan jasa Puskesmas terhadap kepuasan pasien di Puskesmas Gunungpati Semarang. yang menemukan hasil menunjukkan bahwa Berdasarkan hasil analisis SEM dapat disimpulkan bahwa Kehadalan berpengaruh secara langsung terhadap Kepuasan Pasien, karena besarnya pengaruh langsung lebih besar daripada pengaruh tidak langsung melalui Kepuasan Pasien. Masing-masing besarnya pengaruh langsung adalah 13\% untuk Kepuasan Pasien. Adapun persamaan penelitian terdahulu ini dengan penelitian saat ini adalah sama sama menggunakan variabel Kehandalan terhadap Kepuasan Pasien, menggunakan path analisis sedangkan perbedanaannya adalah metode KUalitas pelayanan dan Kepuasan Pasien, populasi dan sampel, lokasi, waktu penelitian dan Menggunakan Regresi Berganda.

3. Pengaruh Daya Tanggap Terhadap Kepuasan Pasien

Telah teruji bahwa Daya tanggap berpengaruh positif Terhadap Kepuasan Pasien dimana Daya tanggap Dapat meliputi Respon atau kesigapan serta kemampuan untuk membantu pelanggan dan meningkatkan kecepatan pelayanannya. Dimensi ini juga dapat menunjukkan kesiapan pekerja untuk melayani pelanggan. Berdasarkan pada hasil penelitian yang menunjukkan adanya pengaruh yang positif dan signifikan antara Daya tanggap terhadap Kepuasan Pasien di Puskesmas Kelua Kabupaten Tabalong, maka diharapkan Puskesmas tersebut dapat lebih meningkatkan Daya tanggap dalam kapasitas sebagai pelayanan masyarakat. Temuan penelitian ini sejalan dengan penelitian yang dilakukan Retno Dwi 2010, dengan judul Analisis pengaruh tingkat kualitas pelayanan jasa Puskesmas terhadap kepuasan pasien di Puskesmas Gunungpati Semarang. yang menemukan hasil menunjukkan bahwa Terdapat pengaruh langsung Kualitas Pelayanan terhadap Kepuasan Pasien akuntansi dan ada pengaruh tidak langsung antara Kualitas pelayanan terhadap Puskesmas Gunungpati Semarang. Adapun persamaan penelitian terdahulu ini dengan penelitian saat ini adalah sama - sama menggunakan variabel Kualitas Pelayanan terhadap Kepuasan Pasien, menggunakan path analisis sedangkan perbedanaannya adalah penelitian saat ini mengembangkan variabel populasi dan sampel, Lokasi penelitian, waktu penelitian dan Menggunakan Regresi Berganda

4. Pengaruh Jaminan Terhadap Kepuasan Pasien

Telah teruji bahwa Jaminan berpengaruh positif Terhadap Kepuasan Pasien dimana Bukti Fisik Dapat meliputi Kemampuan karyawan atas pengetahuan terhadap produk secara tepat, jaminan keselamatan, keterampilan dalam memberikan keamanan, dalam memanfaatkan jasa yang ditawarkan dan kemampuan dalam menanamkan kepercayaan pelanggan terhadap perusahaan. Berdasarkan pada hasil penelitian yang menunjukkan adanya pengaruh yang positif dan signifikan antara Jaminan terhadap Kepuasan Pasien di Puskesmas Kelua Kabupaten Tabalong, maka diharapkan Puskesmas tersebut dapat lebih 
meningkatkan Jaminan dalam kapasitas sebagai pelayanan masyarakat. Temuan penelitian ini sejalan dengan penelitian yang dilakukan Retno Dwi 2010, dengan judul Analisis pengaruh tingkat kualitas pelayanan jasa Puskesmas terhadap kepuasan pasien di Puskesmas Gunungpati Semarang. yang menemukan hasil menunjukkan bahwa Terdapat pengaruh langsung Kualitas Pelayanan terhadap Kepuasan Pasien akuntansi dan ada pengaruh tidak langsung antara Kualitas pelayanan terhadap Puskesmas Gunungpati Semarang. Adapun persamaan penelitian terdahulu ini dengan penelitian saat ini adalah sama - sama menggunakan variabel Kualitas Pelayanan terhadap Kepuasan Pasien, menggunakan path analisis sedangkan perbedanaannya adalah penelitian saat ini mengembangkan variabel populasi dan sampel, Lokasi penelitian, waktu penelitian dan Menggunakan Regresi Berganda

5. Pengaruh Kepedulian Terhadap Kepuasan Pasien

Telah teruji bahwa Kepedulian berpengaruh positif Terhadap Kepuasan Pasien dimana Kepedulian Dapat meliputi Memberikan perhatian secara individual penuh kepada pasien dan keluarganya, seperti kemudahan untuk menghubungi, kemampuan untuk berkomunikasi, perhatian yang tinggi kepada pasien. Berdasarkan pada hasil penelitian yang menunjukkan adanya pengaruh yang positif dan signifikan antara Kepedulian terhadap Kepuasan Pasien di Puskesmas Kelua Kabupaten Tabalong, maka diharapkan Puskesmas tersebut dapat lebih meningkatkan Kepedulian dalam kapasitas sebagai pelayanan masyarakat. Temuan penelitian ini sejalan dengan penelitian yang dilakukan Retno Dwi 2010, dengan judul Analisis pengaruh tingkat kualitas pelayanan jasa Puskesmas terhadap kepuasan pasien di Puskesmas Gunungpati Semarang. yang menemukan hasil menunjukkan bahwa Terdapat pengaruh langsung Kualitas
Pelayanan terhadap Kepuasan Pasien akuntansi dan ada pengaruh tidak langsung antara Kualitas pelayanan terhadap Puskesmas Gunungpati Semarang. Adapun persamaan penelitian terdahulu ini dengan penelitian saat ini adalah sama - sama menggunakan variabel Kualitas Pelayanan terhadap Kepuasan Pasien, menggunakan path analisis sedangkan perbedanaannya adalah penelitian saat ini mengembangkan variabel populasi dan sampel, Lokasi penelitian, waktu penelitian dan Menggunakan Regresi Berganda

6. Pengaruh Bukti Fisik Terhadap Word of Mouth (WOM)

Telah teruji bahwa Bukti Fisik berpengaruh positif Terhadap Word of Mouth (WOM) dimana WOM yang baik merupakan gambaran kualitatif tentang bukti fisik yang baik dari puskesmas tersebut. Berdasarkan hasil di atas maka dapat dikemukakan bahwa Bukti Fisik adalah Kemampuan puskesmas dalam menunjukkan eksistensinya kepada masyarakat, dapat meliputi fasilitas fisik (gedung, buku, meja dan kursi, dan sebagainya), teknologi (peralatan dan perlengkapan yang dipergunakan), serta penampilan pegawai. Dan apabila Bukti fisik ini baik kelihatan di mata masyarakat maka akan menaikkan Word of Mouth (WOM) yang baik di masyarakat tentang puskesmas ini. Temuan penelitian ini sejalan dengan penelitian yang dilakukan Rahmalani Yonika. 2018. Pengaruh Kualitas Pelayanan Terhadap Word Of Mouth Dengan Kepuasan Konsumen Sebagai Variabel Intervening (Studi Pada Wedding Organizer “ Rahma Gunter “ Bandar Lampung). Penelitian ini bertujuan untuk mengetahui Bukti Fisik berpengaruh terhadap Word of Mouth (WOM) dengan kepuasan konsumen sebagai pemediasi pada wedding organizer "Rahma Gunter" Bandar Lampung. Penelitian ini memperlihatkan bahwa Bukti Fisik secara parsial memiliki pengaruh positif 
dan signifikan terhadap kepuasan pelanggan, kualitas pelayanan berpengaruh positif dan signifikan terhadap Word Of Mouth, serta kualitas layanan dan kepuasan konsumen memiliki pengaruh positif dan signifikan terhadap Word Of Mouth (WOM), pada wedding organizer "Rahma Gunter" Bandar Lampung. Adapun persamaan penelitian terdahulu ini dengan penelitian saat ini adalah sama - sama menggunakan variabel Kualitas Pelayanan terhadap Word of Mouth (WOM) sedangkan perbedanaannya adalah penelitian saat ini populasi dan sampel. Lokasi, serta waktu penelitian, analisis yang dipergunakan Regresi Linear Berganda

7. Pengaruh Kehandalan Terhadap Word of Mouth (WOM)

Telah teruji bahwa Kehandalan berpengaruh positif Terhadap Word of Mouth (WOM) dimana WOM yang baik merupakan gambaran kualitatif tentang bukti fisik yang baik dari puskesmas tersebut. Berdasarkan hasil di atas maka dapat dikemukakan bahwa Kehandalan adalah Dimensi ini menunjukkan kemampuan untuk memberikan pelayanan dengan sesuai janji yang ditawarkan. Penilaian ini berkaitan dengan ketepatan waktu pelayanan waktu mengurus pendaftaran, waktu pengobatan/pemeriksaan, kesesuaian antara harapan dan realisasi waktu bagi pasien. Dan apabila Kehandalan ini baik maka akan menaikkan Word of Mouth (WOM) yang positif di masyarakat. Temuan penelitian ini sejalan dengan penelitian yang dilakukan Rahmalani Yonika. 2018. Pengaruh Kualitas Pelayanan Terhadap Word Of Mouth Dengan Kepuasan Konsumen Sebagai Variabel Intervening (Studi Pada Wedding Organizer “ Rahma Gunter " Bandar Lampung). Penelitian ini bertujuan untuk mengetahui Kehandalan berpengaruh terhadap Word of Mouth (WOM) dengan kepuasan konsumen sebagai pemediasi pada wedding organizer "Rahma Gunter" Bandar
Lampung. Penelitian ini memperlihatkan bahwa Kehandalan secara parsial memiliki pengaruh positif dan signifikan terhadap kepuasan pelanggan, kualitas pelayanan berpengaruh positif dan signifikan terhadap Word Of Mouth, serta kualitas layanan dan kepuasan konsumen memiliki pengaruh positif dan signifikan terhadap Word Of Mouth (WOM), pada wedding organizer "Rahma Gunter" Bandar Lampung. Adapun persamaan penelitian terdahulu ini dengan penelitian saat ini adalah sama - sama menggunakan variabel Kualitas Pelayanan terhadap Word of Mouth (WOM) sedangkan perbedanaannya adalah penelitian saat ini populasi dan sampel. Lokasi, serta waktu penelitian, analisis yang dipergunakan Regresi Linear Berganda

8. Pengaruh Daya Tanggap Terhadap Word of Mouth (WOM)

Telah teruji bahwa Daya tanggap berpengaruh positif Terhadap Word of Mouth (WOM) dimana WOM yang baik merupakan gambaran kualitatif tentang Daya tanggap yang baik dari puskesmas tersebut. Berdasarkan hasil di atas maka dapat dikemukakan bahwa Daya tanggap adalah Respon atau kesigapan serta kemampuan untuk membantu pelanggan dan meningkatkan kecepatan pelayanannya. Dimensi ini juga dapat menunjukkan kesiapan pekerja untuk melayani pelanggan. Dan apabila Daya tanggap ini baik maka akan menaikkan Word of Mouth (WOM) yang positif di masyarakat. Temuan penelitian ini sejalan dengan penelitian yang dilakukan Rahmalani Yonika. 2018. Pengaruh Kualitas Pelayanan Terhadap Word Of Mouth Dengan Kepuasan Konsumen Sebagai Variabel Intervening (Studi Pada Wedding Organizer " Rahma Gunter “ Bandar Lampung). Penelitian ini bertujuan untuk mengetahui Daya tanggap berpengaruh terhadap Word of Mouth (WOM) dengan kepuasan konsumen sebagai pemediasi pada wedding organizer "Rahma Gunter" 
Bandar Lampung. Penelitian ini memperlihatkan bahwa Bukti Fisik secara parsial memiliki pengaruh positif dan signifikan terhadap kepuasan pelanggan, kualitas pelayanan berpengaruh positif dan signifikan terhadap Word Of Mouth, serta kualitas layanan dan kepuasan konsumen memiliki pengaruh positif dan signifikan terhadap Word Of Mouth (WOM), pada wedding organizer "Rahma Gunter" Bandar Lampung. Adapun persamaan penelitian terdahulu ini dengan penelitian saat ini adalah sama - sama menggunakan variabel Kualitas Pelayanan terhadap Word of Mouth (WOM) sedangkan perbedanaannya adalah penelitian saat ini populasi dan sampel. Lokasi, serta waktu penelitian, analisis yang dipergunakan Regresi Linear Berganda

9. Pengaruh Jaminan Terhadap Word of Mouth (WOM)

Telah teruji bahwa Jaminan berpengaruh positif Terhadap Word of Mouth (WOM) dimana WOM yang baik merupakan gambaran kualitatif tentang Jaminan yang baik dari puskesmas tersebut. Berdasarkan hasil di atas maka dapat dikemukakan bahwa Jaminan adalah Kemampuan karyawan atas pengetahuan terhadap produk secara tepat, jaminan keselamatan, keterampilan dalam memberikan keamanan, dalam memanfaatkan jasa yang ditawarkan dan kemampuan dalam menanamkan kepercayaan pelanggan terhadap Puskesmas. Dan apabila Jaminan ini baik maka akan menaikkan Word of Mouth (WOM) yang positif di masyarakat. Temuan penelitian ini sejalan dengan penelitian yang dilakukan Rahmalani Yonika. 2018. Pengaruh Kualitas Pelayanan Terhadap Word Of Mouth Dengan Kepuasan Konsumen Sebagai Variabel Intervening (Studi Pada Wedding Organizer " Rahma Gunter " Bandar Lampung). Penelitian ini bertujuan untuk mengetahui Jaminan berpengaruh terhadap Word of Mouth (WOM) dengan kepuasan konsumen sebagai pemediasi pada wedding organizer "Rahma Gunter" Bandar Lampung. Penelitian ini memperlihatkan bahwa Jaminan secara parsial memiliki pengaruh positif dan signifikan terhadap kepuasan pelanggan, kualitas pelayanan berpengaruh positif dan signifikan terhadap Word Of Mouth, serta kualitas layanan dan kepuasan konsumen memiliki pengaruh positif dan signifikan terhadap Word Of Mouth (WOM), pada wedding organizer "Rahma Gunter" Bandar Lampung. Adapun persamaan penelitian terdahulu ini dengan penelitian saat ini adalah sama - sama menggunakan variabel Kualitas Pelayanan terhadap Word of Mouth (WOM) sedangkan perbedanaannya adalah penelitian saat ini populasi dan sampel. Lokasi, serta waktu penelitian, analisis yang dipergunakan Regresi Linear Berganda

10. Pengaruh Kepedulian Terhadap Word of Mouth (WOM)

Telah teruji bahwa Kepedulian berpengaruh positif Terhadap Word of Mouth (WOM) dimana WOM yang baik merupakan gambaran kualitatif tentang Kepedulian yang baik dari puskesmas tersebut. Berdasarkan hasil di atas maka dapat dikemukakan bahwa Kepedulian dengan memberikan perhatian secara penuh dan tulus kepada pasien dan keluarganya dalam melayani, seperti kemudahan untuk menghubungi, kemampuan untuk berkomunikasi, perhatian yang tinggi kepada pasien. Dan apabila Kepedulian ini dilaksanakan baik maka akan menaikkan Word of Mouth (WOM) yang positif di masyarakat tentang kehandalan puskesmas dalam melayani. Temuan penelitian ini sejalan dengan penelitian yang dilakukan Rahmalani Yonika. 2018. Pengaruh Kualitas Pelayanan Terhadap Word Of Mouth Dengan Kepuasan Konsumen Sebagai Variabel Intervening (Studi Pada Wedding Organizer " Rahma Gunter " Bandar Lampung). Penelitian ini bertujuan untuk mengetahui Kepedulian berpengaruh terhadap Word of Mouth 
(WOM) dengan kepuasan konsumen sebagai pemediasi pada wedding organizer "Rahma Gunter" Bandar Lampung. Penelitian ini memperlihatkan bahwa Kepedulian secara parsial memiliki pengaruh positif dan signifikan terhadap kepuasan pelanggan, kualitas pelayanan berpengaruh positif dan signifikan terhadap Word Of Mouth, serta Kepedulian dan kepuasan konsumen memiliki pengaruh positif dan signifikan terhadap Word Of Mouth (WOM), pada wedding organizer "Rahma Gunter" Bandar Lampung. Adapun persamaan penelitian terdahulu ini dengan penelitian saat ini adalah sama - sama menggunakan variabel Kualitas Pelayanan terhadap Word of Mouth (WOM) sedangkan perbedanaannya adalah penelitian saat ini populasi dan sampel. Lokasi, serta waktu penelitian, analisis yang dipergunakan Regresi Linear Berganda

11. Pengaruh Kepuasan Pasien Terhadap Word of Mouth (WOM)

Telah teruji bahwa Bukti Fisik berpengaruh positif Terhadap Word of Mouth (WOM) dimana WOM yang baik merupakan gambaran kualitatif tentang bukti fisik yang baik dari puskesmas tersebut. Berdasarkan hasil di atas maka dapat dikemukakan bahwa Bukti Fisik adalah Kemampuan suatu perusahaan dalam menunjukkan eksistensinya kepada pihak eksternal, dapat meliputi fasilitas fisik (gedung, buku, meja dan kursi, dan sebagainya), teknologi (peralatan dan perlengkapan yang dipergunakan), serta penampilan pegawai. Dan apabila Bukti fisik ini baik maka akan menaikkan Word of Mouth (WOM) yang positif di masyarakat. Temuan penelitian ini sejalan dengan penelitian yang dilakukan Rahmalani Yonika. 2018. Pengaruh Kepuasan Konsumen Terhadap Word Of Mouth. Penelitian ini bertujuan untuk mengetahui Kepuasan Konsumen berpengaruh terhadap Word of Mouth (WOM) pada wedding organizer "Rahma Gunter" Bandar
Lampung. Penelitian ini memperlihatkan bahwa Kepuasan Konsumen berpengaruh positif dan signifikan terhadap Word Of Mouth, serta kualitas layanan dan kepuasan konsumen memiliki pengaruh positif dan signifikan terhadap Word Of Mouth (WOM), pada wedding organizer "Rahma Gunter" Bandar Lampung. Adapun persamaan penelitian terdahulu ini dengan penelitian saat ini adalah sama - sama menggunakan variabel Kepuasan Konsumen terhadap Word of Mouth (WOM) sedangkan perbedanaannya adalah penelitian saat ini populasi dan sampel. Lokasi, serta waktu penelitian, analisis yang dipergunakan Regresi Linear Berganda

\section{Kesimpulan}

1. dapat pengaruh positif dan signifikan Bukti Fisik terhadap Kepuasan Pasien artinya H-1 diterima. Bukti Fisik memiliki pengaruh yang signifikan terhadap Kepuasan Pasien

2. Terdapat pengaruh positif dan signifikan Kehandalan terhadap Kepuasan Pasien Puskesmas artinya H2 diterima. Kehandalan memiliki pengaruh yang signifikan terhadap Kepuasan Pasien

3. Terdapat pengaruh positif dan signifikan Daya tanggap terhadap Kepuasan Pasien artinya H-3 diterima. Daya tanggap memiliki pengaruh yang signifikan terhadap Kepuasan Pasien

4. Terdapat pengaruh positif dan signifikan Jaminan terhadap Kepuasan Pasien Puskesmas artinya H-4 diterima. Jaminan memiliki pengaruh yang signifikan terhadap Kepuasan Pasien

5. Terdapat pengaruh positif dan signifikan Kepedulian terhadap Kepuasan Pasien artinya H-5 diterima. Kepedulian memiliki pengaruh yang signifikan terhadap Kepuasan Pasien

6. Terdapat pengaruh Positif dan significant Bukti Fisik Terhadap Word Of Mouth (WOM) artinya H-6 diterima. Bukti Fisik memiliki pengaruh 
yang signifikan terhadap Word Of Mouth (WOM).

7. Terdapat pengaruh Positif dan significant Kehandalan Terhadap Word Of Mouth (WOM) artinya H-7 diterima. Kehandalan memiliki pengaruh yang signifikan terhadap Word Of Mouth (WOM)

8. Terdapat pengaruh Positif dan significant Daya tanggap Terhadap Word Of Mouth (WOM) artinya H-8 diterima. Daya tanggap memiliki pengaruh yang signifikan terhadap Word Of Mouth (WOM)

9. Terdapat pengaruh Positif dan significant Jaminan Terhadap Word Of Mouth (WOM) artinya H-9 diterima. Jaminan memiliki pengaruh yang signifikan terhadap Word Of Mouth (WOM)

10. Terdapat pengaruh Positif dan significant Kepedulian Terhadap Word Of Mouth (WOM) artinya H-10 diterima. Kepedulian memiliki pengaruh yang signifikan terhadap Word Of Mouth (WOM).

11. Terdapat pengaruh Positif dan significant Kepuasan Pasien Puskesmas Terhadap Word Of Mouth (WOM) artinya $\mathrm{H}-11$ diterima. Kepuasan Pasien Puskesmas memiliki pengaruh yang signifikan terhadap prestasi.

\section{Saran}

1. Bukti Fisik yang unggul akan dapat menjadi modal untuk dapat membantu Puskesmas meningkatkan Kepuasan Pasien nya. Untuk itu diperlukan upaya agar Puskesmas terus mengembangkan Bukti Fisik serta memperhatikan aspekaspek Bukti Fisik yang dapat meningkatkan Kepuasan Pasien Puskesmas . Diharapkan Puskesmas untuk selalu meningkatkan kompetensinya dengan meningkatkan kemampuannya dalam menunjukkan eksistensinya kepada pihak eksternal. Penampilan dan kemampuan sarana dan prasarana fisik Puskesmas yang dapat diandalkan serta keadaan lingkungan sekitarnya merupakan salah satu cara
Puskesmas dalam menyajikan kualitas layanan terhadap pelanggan. Dapat meliputi fasilitas fisik (gedung, buku, meja dan kursi, dan sebagainya), teknologi (peralatan dan perlengkapan yang dipergunakan), serta penampilan petugas yang baik.

2. Semakin Baik Kehandalan maka semakin tinggi pula Kepuasan Pasien Puskesmas. Kehandalan di tingkatkan dengan menaikkan kemampuan Puskesmas memberikan pelayanan sesuai dengan apa yang dijanjikan secara akurat dan terpercaya. Kinerja harus sesuai dengan harapan Pasien yang tercermin dari ketepatan waktu, pelayanan yang sama untuk semua pelanggan tanpa kesalahan, sikap simpatik dan akurasi yang tinggi untuk menaikkan Kepuasan Pasien Puskesmas .

3. Peningkatan Daya tanggap harus diperhatikan oleh Puskesmas. Puskesmas harus mampu menaikkan Daya tanggap yaitu dengan menaikkan Kemauan untuk membantu pasien dan memberikan jasa dengan cepat dan tepat dengan penyampaian informasi yang jelas. Mengabaikan dan membiarkan pasien menunggu tanpa alasan jelas menyebabkan persepsi yang negative dalam kualitas pelayanan sehingga dapat meningkatkan Kepuasan Pasien Puskesmas.

4. Semakin Baik Jaminan yang diberikan maka semakin tinggi pula Kepuasan Pasien Puskesmas. Jaminan di tingkatkan yaitu menambah pengetahuan, kesopan-santunan dan kemampuan para petugas kesehatan puskesmas untuk menumbuhkan rasa percaya para pasien kepada puskesmas.dengan untuk menaikkan Kepuasan Pasien Puskesmas.

5. Peningkatan Rasa Kepedulian harus diperhatikan oleh Puskesmas. Puskesmas harus mampu menaikkan rasa Kepedulian dalam melayani yaitu dengan menaikkan perhatian yang tulus dan bersifat individual atau pribadi yang diberikan kepada Pasien dengan berupaya memahami keinginan pasien 
dimana suatu puskesmas diharapkan memiliki suatu pengertian dan pengetahuan tentang pelanggan, memahami kebutuhan pelanggan secara spesifik, serta memiliki waktu pengoperasian yang nyaman bagi pelanggansehingga dapat meningkatkan Kepuasan Pasien Puskesmas.

6. Sebaiknya Puskesmas meningkatkan Bukti Fisik dalam menaikkan kualitas pelayanan dan tentunya mendukung terhadap terciptanya Word Of Mouth (WOM) yang baik .

7. Sebaiknya Puskesmas meningkatkan Kehandalan dalam menaikkan kualitas pelayanan dan tentunya mendukung terhadap terciptanya Word Of Mouth (WOM) yang baik .

8. Sebaiknya Puskesmas meningkatkan Daya tanggap dalam menaikkan kualitas pelayanan dan tentunya mendukung terhadap terciptanya Word Of Mouth (WOM) yang baik .

9. Sebaiknya Puskesmas meningkatkan Jaminan dalam menaikkan kualitas pelayanan dan tentunya mendukung terhadap terciptanya Word Of Mouth (WOM) yang baik .

10. Sebaiknya Puskesmas meningkatkan Rasa Kepedulian dalam menaikkan kualitas pelayanan dan tentunya mendukung terhadap terciptanya Word Of Mouth (WOM) yang baik .

11. Sebaiknya Puskesmas meningkatkan Kualitas Pelayanan dalam dan tentunya mendukung terhadap terciptanya Word Of Mouth (WOM) yang baik di masyarakat.

12. Untuk peneliti selanjutnya diharapkan dapat meneliti variabel-variabel lain yang mempengaruhi prestasi belajar Puskesmas di luar variabel yang penulis teliti.

\section{DAFTAR PUSTAKA}

A. Parasuraman., 2014., The Behaviorial Consequenses of Service Quality. New Jersey : Prentince Hall.

Al-Assaf. 2009. Mutu Pelayanan Kesehatan. Jakarta : EGC.
Anwar Prabu Mangkunegara, 2012, Manajemen Sumber Daya Manusia., Cetakan Ke-2, PT. Remaja Rosda Karya, Bandung.

Arikunto .2012. Prosedur Penelitian: Suatu Pendekatan Praktik. Rineka Cipta. Jakarta.

Azwar. S .2012. Sikap Manusia Teori dan Pengukurannya. Pustak. Pelajar. Yogyakarta.

Budiman, dkk., 2013. Kapita Selekta Kuisioner Pengetahuan Dan Sikap. Dalam Penelitian Kesehatan. Salemba. Jakarta.

Firdian, dkk., 2012. Metode Servqual dan Six Sigma Dalam Menganalisis Kualitas Layanan PT. PLN (Persero) Unit

Pelayanan Jaringan (UPJ) . Dinoyo. Malang.

Firman Firdausy .2007. Pengaruh Kualitas Jasa, Terhadap Kepuasan Pasien Pada Rumah Sakit Umum Daerah Kabupaten Gresik

Harris, K., Grewal, D., Mohr, L., Bernhardt, K., 2006.Consumer responses toservice recovery strategiesThe moderating role of online versus offlineenvironment.Journal of Business Research 59 (4), 425431.

Hayati .2013. Analisa Persepsi Mutu Pelayanan Terhadap Kepuasan Pasien di Ruang Rawat Inap RSUD Langsa. USU. Medan.

Herdita Sectio Caesaria .2010. Pengaruh Kualitas Pelayanan Terhadap Kepuasan Pasien Puskesmas (Study Kasus Pada Puskesmas Simpur Kota Bandar Lampung). Universitas Lampung. Lampung.

Kaihatu, 2012. Good Corporate Governance dan Penerapannya di. Indonesia. Jurnal Manajemen dan Kewirausahaan, Vol .8, No. 1, Maret 2012.

Kotler Philip, 2012, Manajemen Pemasaran, edisi Millenium, terjemahan Hendra Teguh, dan 
Ronny A. Rusli, Penerbit : Prenhallindo, Jakarta.

2013. Prinsip-prinsip Pemasaran. Edisi13. Jilid 1. Prenhallindo Jakarta.

Nunuk Herawati. 2015. Pengaruh Kualitas Pelayanan Puskesmas Terhadap Kepuasan Pasien Pengguna Kartu Pemeliharaan Kesehatan Masyarakat Surakarta (PKMS) DI Surakarta. Sekolah Tinggi Ilmu Ekonomi AUB Surakarta. Surakarta

Pohan.I.S. 2012. Jaminan Mutu Layanan Kesehatan. Jakarta:Penerbit EGC.

Pontevia et al WOM sebagai bentuk komunikasi interpersonal, New Jersey : Prentince Hall 2008

Rismiati dan Suratno .2011. segmentasi pasar. Gunung Agung. Jakarta

Santoso, Singgih .2008. Statistik Parametik. PT Gramedia Pustaka. Jakarta.

Satrianegara, M. Fais. Organisasi dan Manajemen Pelayanan Kesehatan Teori dan Aplikasi dalam Pelayanan Puskesmas dan Rumah Sakit. Jakarta : Salemba Medika, 2014.

Sernovitz. (2009). Word of Mouth Marketing. Jakarta: Gramedia Pustaka Utama.

Silverman, George. (2001). The Secrets of Word of Mouth Marketing: How to Trigger Exponential Sales through Runaway Word of Mouth. New York: AMACOM.

Singarimbun, Masri .2012. Metode Penelitian Survai. Pustaka Belajar. Jakarta.

Sri Monarita, .2012. Pengaruh Persepsi Kualitas Pelayanan Terhadap Kepuasan Pasien Rawat Inap $R S U$. USU. Medan.

Sritua, 2012. Metodologi Penelitian Ekonomi. Universitas. Indonesia. Jakarta.

Sugiyono .2012. Metode Penelitian Pendidikan Pendekatan
Kuantitatif, kualitatif, dan $R \& D$. Alfabeta. Bandung.

Sularso, Sri .2011. Metode Penelitian Akuntansi Sebuah Pendekatan.Gramedia Jakarta.

Tjiptono .2012. Strategi Pemasaran, Edisi 2, ANDI: Yogyakarta.

Tjiptono dan Chandra, 2012. Pemasaran Strategik. ANDI. Yogyakarta,

Tjiptono, dkk., .2013. Pemasaran Strategik. ANDI. Yogyakarta. . 2013. Strategi Pemasaran, Edisi 3, ANDI: Yogyakarta.

Umar .2012. Metode Penelitian Untuk Skripsi dan Tesis Bisnis". Raja Grafindo Persada. Jakarta

Undang Undang 1945 hasil amandemen dalam pasal $28 \mathrm{H}$ ayat .1),

Utama, 2013. Total Quality Management", PT Gramedia Pustaka Utama: Jakarta.

Yessy Gusti Eka Pratiwi. 2018. Pengaruh Kualitas Pelayanan Terhadap Kepuasan Masyarakat Sebagai Pasien Di Puskesmas Sering Kecamatan Medan Tembung. USU. Medan

Yuliarmi, Ni Nyoman dan Putu Riyasa.2007. Analisis FaktorFaktor Yang Mempengaruhi Kepuasan PelangganTerhadap Pelayanan PDAM Kota Denpasar. Denpasar: Buletin Studi Ekonomi Volume 12 Nomor 1 Tahun 2007. 